OPEN ACCESS

Edited by:

Lyne Morissette,

M - Expertise Marine, Canada

Reviewed by:

Sophie Dennison,

TeleVet Imaging Solutions, PLLC,

United States

Virginie Papadopoulou, University of North Carolina at Chapel

Hill, United States

*Correspondence:

Andreas Fahlman

afahlman@whoi.edu

${ }^{\dagger}$ These authors have contributed equally to this work

Specialty section: This article was submitted to

Aquatic Physiology,

a section of the journal

Frontiers in Marine Science

Received: 25 August 2020 Accepted: 08 January 2021

Published: 05 February 2021

Citation:

Fahlman A, Moore MJ and Wells RS (2021) How Do Marine Mammals Manage and Usually Avoid Gas Emboli Formation and Gas Embolic Pathology? Critical Clues

From Studies of Wild Dolphins.

Front. Mar. Sci. 8:598633.

doi: 10.3389/fmars.2021.598633

\section{How Do Marine Mammals Manage and Usually Avoid Gas Emboli Formation and Gas Embolic Pathology? Critical Clues From Studies of Wild Dolphins}

\author{
Andreas Fahlman ${ }^{1,2 *+}$, Michael J. Moore ${ }^{3 t}$ and Randall S. Wells ${ }^{4 t}$ \\ ${ }^{1}$ Global Diving Research, Inc., Ottawa, ON, Canada, ${ }^{2}$ Fundación Oceanogràfic de la Comunitat Valenciana, Valencia, Spain, \\ ${ }^{3}$ Biology Department, Woods Hole Oceanographic Institution, Woods Hole, MA, United States, ${ }^{4}$ Chicago Zoological \\ Society's Sarasota Dolphin Research Program, c/o Mote Marine Laboratory, Sarasota, FL, United States
}

Decompression theory has been mainly based on studies on terrestrial mammals, and may not translate well to marine mammals. However, evidence that marine mammals experience gas bubbles during diving is growing, causing concern that these bubbles may cause gas emboli pathology (GEP) under unusual circumstances. Marine mammal management, and usual avoidance, of gas emboli and GEP, or the bends, became a topic of intense scientific interest after sonar-exposed, massstranded deep-diving whales were observed with gas bubbles. Theoretical models, based on our current understanding of diving physiology in cetaceans, predict that the tissue and blood $\mathrm{N}_{2}$ levels in the bottlenose dolphin (Tursiops truncatus) are at levels that would result in severe DCS symptoms in similar sized terrestrial mammals. However, the dolphins appear to have physiological or behavioral mechanisms to avoid excessive blood $\mathrm{N}_{2}$ levels, or may be more resistant to circulating bubbles through immunological/biochemical adaptations. Studies on behavior, anatomy and physiology of marine mammals have enhanced our understanding of the mechanisms that are thought to prevent excessive uptake of $\mathrm{N}_{2}$. This has led to the selective gas exchange hypothesis, which provides a mechanism how stress-induced behavioral change may cause failure of the normal physiology, which results in excessive uptake of $\mathrm{N}_{2}$, and in extreme cases may cause formation of symptomatic gas emboli. Studies on cardiorespiratory function have been integral to the development of this hypothesis, with work initially being conducted on excised tissues and cadavers, followed by studies on anesthetized animals or trained animals under human care. These studies enabled research on free-ranging common bottlenose dolphins in Sarasota Bay, FL, and off Bermuda, and have included work on the metabolic and cardiorespiratory physiology of both shallow- and deep-diving dolphins and have been integral to better understand how cetaceans can dive to extreme depths, for long durations.

Keywords: diving physiology, lung function, dive response, plasticity, cardiac output, selective gas exchange hypothesis, gas embolic pathology, decompression sickness 


\section{INTRODUCTION: GAS EMBOLIC PATHOLOGY (GEP) IN BREATH-HOLD DIVING MARINE VERTEBRATES; THE PARADIGM SHIFT}

Until recently, it has been widely assumed that breath-hold diving marine vertebrates had adaptations that protected them from the development of decompression sickness (DCS), or caisson disease, as they returned from a dive (Scholander, 1940). Reports of gas emboli in stranded deep-diving whales therefore surprised the biological community, and it was suggested that these were similar to bubble formation in human divers that may cause symptomatic DCS (Jepson et al., 2003, 2005; Fernandez et al., 2005). Even though Scholander (1940) reported massive gas emboli leading to death during a single $12 \mathrm{~min}$ forced-dive to $300 \mathrm{~m}$ by a hooded seal (Cystophora cristata), and DCS being reported in humans during both single and repeated breathhold dives, some criticized these initial reports on the basis that DCS is not possible following a single breath-hold dive (Paulev, 1965; Rahn and Yokoyama, 1965; Piantadosi and Thalmann, 2004; Schipke et al., 2006; Lemaitre et al., 2009). Following this, several analyses have attempted to determine the potential causes for these stranding events, which appeared to happen in close temporal and spatial proximity to naval sonar exercises (Cox et al., 2006; Hooker et al., 2012; Bernaldo de Quirós et al., 2019). Among the main working hypotheses were that changes in dive behavior or physiology (e.g., increased dive duration, activity, or ascent rate), or changes in cardiac output, would have resulted in increased $\mathrm{N}_{2}$ uptake, which resulted in the formation of blood and tissue gas bubbles (Cox et al., 2006; Hooker et al., 2012; Blix et al., 2013; Fahlman et al., 2014b; Bernaldo de Quirós et al., 2019). As it is neither desirable nor ethically, legally, or logistically possible to perform controlled studies where marine mammals are exposed to decompression sequences that result in severe trauma, stress, or death, we therefore refer to the symptoms seen in breath-hold diving marine vertebrates as gas embolic pathology (GEP) to distinguish this from symptoms of DCS observed in humans.

In 2012, we began to investigate whether we could (1) detect circulating Microparticles (MP) in the bottlenose dolphin (Tursiops truncatus), and (2) to assess the baseline circulating MP concentration. MPs are small $(0.1-1.0 \mu \mathrm{m})$ membrane lipid bilayer-enclosed vesicles that have been investigated as biomarkers of decompression stress in air breathing divers, and are elevated in relation to increasing decompression stress (Thom et al., 2013). It was hypothesized that if detected in marine mammals, this could be a useful intravascular biomarker of gas bubble formation that could be used to evaluate the magnitude of decompression stress (Fahlman et al., 2016). This research was conducted in Sarasota Bay, Florida, where baseline samples could be obtained from an accessible, well-studied, long-term resident community of wild dolphins, studied since 1970, and including individuals observed over decades, along with five generations of their descendants (Wells, 2009, 2014, 2020), where the health of the resident dolphins has been followed since 1988 (Wells et al., 2004). While this collaboration began with a simple objective, it soon expanded to include investigation into the cardiorespiratory physiology, and energy requirements of bottlenose dolphins.

Prior to this collaboration, physiological studies on cetaceans had mainly used tools and knowledge from work done with animals managed under human care (Ridgway et al., 1969; Ridgway and Howard, 1979; Williams et al., 1993, 1999; Houser et al., 2010; Fahlman et al., 2015). Expanding this work to free-ranging dolphins provided baseline data on respiratory mechanics, lung function, and metabolic requirements on both shallow- and deep-diving common bottlenose dolphins (Fahlman et al., 2015, 2018a,b,c). These studies have provided a framework to better understand the eco-physiology of cetaceans, how changes in the environment may affect cetacean survival, and how man-made stress may cause the development of gas emboli. The ability to study free-ranging dolphins from different habitats, e.g., shallow vs. deep, has allowed empirical testing of the Scholander balloon-pipe model of passive collapse (Scholander, 1940; Bostrom et al., 2008). These studies have suggested that passive collapse is not sufficient to explain the lack of GEP in breath-hold-diving marine species, and that alternative physiological mechanisms are likely to help manage gases during diving (García-Párraga et al., 2018b; Fahlman et al., 2020b).

In this review, we provide a brief summary of current decompression theory, and the pathophysiology of gas emboli. We look at how knowledge from research in terrestrial mammals translates to marine mammals, and how a mixture of theoretical modeling and empirical studies has enabled an investigation of the proposed mechanism of alveolar collapse to protect against diving-related problems. These studies have resulted in the selective gas exchange hypothesis, which provides an explanation for how marine species may have evolved to allow selective exchange of $\mathrm{O}_{2}$ and $\mathrm{CO}_{2}$ while preventing uptake of $\mathrm{N}_{2}$, and how stress may cause this mechanism to fail (Farhi, 1967; GarcíaPárraga et al., 2018b; Fahlman et al., 2020b).

\section{DIVING, GAS EMBOLI AND DECOMPRESSION SICKNESS (DCS)/GAS EMBOLIC PATHOLOGY (GEP)}

Human underwater scuba diving involves exposure to elevated pressures, with the return to the normobaric environment recognized as one of the most dangerous parts of diving due to the risk of the so-called "bends," or DCS. While DCS has also been reported in human breath-hold divers, both during extreme single dives and during repeated diving, it is still poorly investigated (Paulev, 1965; Schipke et al., 2006; FitzClarke, 2009b; Lemaitre et al., 2009). Symptoms of DCS are not only limited to diving, but are also problematic for caisson workers and during aerospace flights, or any other reduction in atmospheric pressure (Mahon and Regis, 2014). It was proposed that breath-hold diving marine mammals have physiological and anatomical adaptations, such as a collapsible chest and atelectatic alveoli, that would help reduce uptake of $\mathrm{N}_{2}$ and thereby reduce the risk of formation of gas emboli and GEP (Scholander, 1940). However, Scholander (1940) described how repeated breath-hold diving could potentially result in excessive $\mathrm{N}_{2}$ uptake and the 
formation of gas emboli, and also performed an experiment in hooded seals that resulted in GEP following a single dive. Since the beginning of this millennium there has been a growing concern that marine mammals, and also turtles, may experience gas emboli that result in trauma, and death under unusual circumstances, such as exposure to sonar or being trapped in a net (Jepson et al., 2003; Fernandez et al., 2005; Cox et al., 2006; Moore et al., 2009; Van Bonn et al., 2011, 2013; Hooker et al., 2012; García-Párraga et al., 2014; Fahlman et al., 2017a; Fernández et al., 2017; Portugues et al., 2018; Bernaldo de Quirós et al., 2019; Parga et al., 2020). So how is $\mathrm{N}_{2}$ taken up and removed during breath-hold diving, and what variables affect the risk of gas emboli and GEP?

\section{UPTAKE, AND REMOVAL OF $\mathrm{N}_{2}$, AND HOW BUBBLES FORM IN SCUBA AND BREATH-HOLD DIVERS}

During exposure to elevated pressure, increased levels of gas dissolve in the tissues of air-breathing animals. The amount of gas dissolved in the tissues is a function of the pressure and duration of the changed pressure. For a scuba diver with a continuous supply of air which is at ambient pressure for the duration of the dive, $\mathrm{N}_{2}$ is taken up during most of the dive and bubbles can cause DCS symptoms following a single dive. For a breath-hold diver, with a limited supply of air and $\mathrm{N}_{2}$, the dynamics are more complicated. While there have been reports of DCS and GEP in human breath-hold divers and marine mammals following a single dive (Scholander, 1940; Lemaitre et al., 2009), risk appears to accumulate during repeated dives with short surface intervals (dive bouts) and may explain why diving species sometimes stop diving for periods of time (Paulev, 1965; Schipke et al., 2006; Fahlman et al., 2007; Hooker et al., 2009).

The $\mathrm{N}_{2}$ tension $\left(\mathrm{PN}_{2}\right)$ of a specific tissue is determined by the tissue half-time $\left(\tau_{\text {tiss } 1 / 2}\right)$, which is the duration to $50 \%$ tissue gas equilibrium (Boycott et al., 1908). Following an increase in environmental pressure, the tissue tension of dissolved gas continues to increase until reaching equilibrium with the environment, at which time the organism is said to be saturated (Figure 1A). For an inert gas like $\mathrm{N}_{2}$, the total concentration in a tissue depends on the total tissue volume, the local blood flow rate, and the solubility of $\mathrm{N}_{2}$ (Boycott et al., 1908; Fahlman et al., 2006; Schipke et al., 2006). For $\mathrm{O}_{2}$, which is continuously utilized and converted and exhaled as $\mathrm{CO}_{2}$, saturation of the tissues will eventually occur but will not only depend on the inhaled gas tension, but also on the diver's $\mathrm{O}_{2}$ consumption and $\mathrm{CO}_{2}$ production rates (Parker et al., 1998; Fahlman et al., 2009). When the diver is returning to the surface and the pressure is decreasing, the blood and tissue gas tensions will eventually exceed the partial pressure of the inhaled gas at which time the diver is becoming supersaturated (Figure 1A). At this point, the gas may come out of solution and form bubbles. While asymptomatic microbubbles can occur even during decompressions from shallow depth (Eckenhoff et al., 1990), if the supersaturation is excessive they may grow and could cause either direct tissue or vascular damage

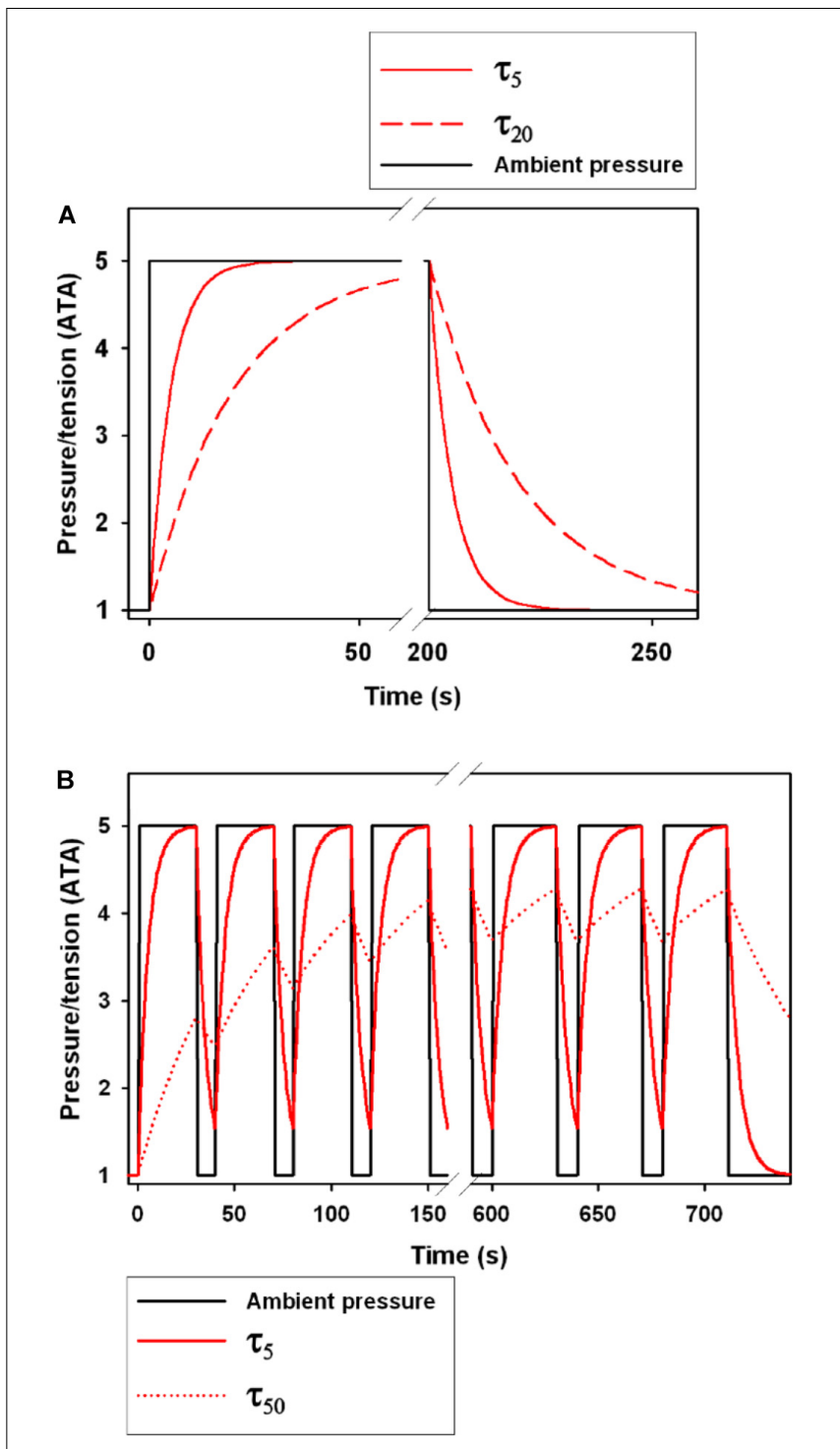

FIGURE 1 | The effect of the tissue half-time $\left(\tau_{\text {tiss } 1 / 2}, \tau\right.$ in figure legend) on gas tension following a step change in ambient pressure. (A) shows a single dive to 5 ATA ( $40 \mathrm{~m}$ ) with a step change in pressure. Black solid line shows the ambient pressure, and the red lines show changes in tension for a $\tau_{\text {tiss } 1 / 2}$ of $5 s$ ( $\tau_{5}$, solid red line) and $20 s$ ( $\tau_{20}$, broken red line). The area under the curve following decompression is the level of supersaturation and the greater the area the greater the likelihood of bubble formation (Berghage et al., 1974; Weathersby et al., 1984; Fahlman, 2017). (B) shows 18 repeated compression and decompression events to 5 ATA with time at pressure at $30 \mathrm{~s}$ and time at 1 ATA at $10 \mathrm{~s}$. The solid and broken red lines are the tensions for a $\tau_{\text {tiss } 1 / 2}$ of $5 s\left(\tau_{5}\right)$ and $50 s\left(\tau_{50}\right)$, respectively.

or blockage, or initiate an immune response (Ward et al., 1987, 1990; Kayar et al., 1997; Thom et al., 2011, 2012, 2013, 2015). It is known that terrestrial mammals and humans can cope with some supersaturation and asymptomatic gas bubble formation, but any decompression has a finite probability of DCS (Berghage et al., 1974; Weathersby et al., 1984; Lillo et al., 2002; Fahlman, 2017). Asymptomatic bubbles may also be common in breathhold diving marine vertebrates (Van Bonn et al., 2011, 2013; 
Dennison et al., 2012a,b), and may over a lifetime of repeated diving cause osteonecrosis in some species (Moore and Early, 2004), or symptomatic GEP in unusual circumstances (Fernandez et al., 2005; García-Párraga et al., 2014; Fernández et al., 2017).

For an air breathing organism with a supply of air, e.g., scuba, it has been shown that $\mathrm{O}_{2}$ can contribute to DCS during rapid decompressions (Lillo, 1988; Lillo and Maccallum, 1991; Parker et al., 1998). However, $\mathrm{O}_{2}$ is not considered a potent gas for DCS in recreational scuba divers since decompressions are generally slow enough to allow sufficient time for the $\mathrm{O}_{2}$ to be metabolized and the partial pressure of $\mathrm{O}_{2}$ is limited to avoid $\mathrm{O}_{2}$ toxicity. In breath-hold divers, the $\mathrm{O}_{2}$ partial pressure will be elevated during a brief period during descent, but rapidly metabolized and therefore not increasing DCS/GEP risk. Excessive levels of $\mathrm{CO}_{2}$ may initiate and increase the rate of bubble formation (McElroy et al., 1944; Harris et al., 1945; Harvey, 1945; Behnke, 1951). It is well established both in humans and marine mammals that blood and tissue $\mathrm{CO}_{2}$ levels increase during diving, and may be exacerbated when disturbed as the animal tries to escape (Rahn and Yokoyama, 1965; Kooyman et al., 1973; Reed et al., 1994; Boutilier et al., 2001; Fahlman et al., 2008; DeRuiter et al., 2013). Interestingly, elevated levels of $\mathrm{CO}_{2}$ have been reported in stranded cetaceans, and it was suggested that elevated levels of $\mathrm{CO}_{2}$, through elevated metabolism, could have helped initiate gas bubble formation and exacerbated symptoms (Bernaldo de Quirós et al., 2012). Thus, to better understand and predict the potential risk of DCS and formation of $\mathrm{N}_{2}$ gas emboli, understanding blood flow and the metabolic rate are important.

\section{SYMPTOMS AND SUSCEPTIBILITY}

The first hyperbaric studies originated at the beginning of the twentieth century, where it was shown that a rapid decompression in man to half the pressure appeared to be safe (Boycott et al., 1908). From these studies, the concept of a critical supersaturation ratio was introduced and the first dive tables were developed. The etiology of DCS is still poorly understood, and there is considerable within- and betweensubject variability in susceptibility and detectable venous gas emboli post-dive (Berghage et al., 1974; Weathersby et al., 1984; Fahlman, 2017). Furthermore, even when the best developed guidelines are followed, DCS still occurs on occasion. While it is generally accepted that the symptoms are caused by the bubbles formed during the decompression phase, the large variation in risk may indicate secondary issues such as variation in blood flow (Berghage et al., 1979; Fahlman, 2017), involvement of the immune system (Ward et al., 1987, 1990; Kayar et al., 1997; Thom et al., 2013), and modification of the endothelial surface of blood vessels (Mollerlokken et al., 2006; Yang et al., 2011). It has also been shown that the probability of DCS is seldom certain for any hyperbaric exposure (Berghage et al., 1974; Weathersby et al., 1984; Fahlman, 2017), but it is well established that the risk varies with the total pressure (depth of the dive), the dive duration, and the ascent rate (Figure 2; Flynn and Lambertsen, 1971; Weathersby et al., 1992; Fahlman et al., 2001; Fahlman, 2017). It is known that the risk of DCS varies with body mass, and larger species, at least in the laboratory, are more susceptible for the same degree of supersaturation (Berghage et al., 1979; Lillo et al., 2002; Fahlman, 2017). As metabolic rate and blood flow, and thereby gas uptake or removal, correlate with body mass, it has been suggested that this variation in risk among species is mainly due to variation in cardiac output (Fahlman, 2017). The importance of blood flow to alter risk may also explain other proposed risk factors such as exercise, adiposity, age, and sex (Robertson, 1992; Broome et al., 1994, 1995; Vann et al., 2011), but among these, body mass is the only risk factor without conflicting results (Berghage et al., 1979; Fahlman et al., 2001; Lillo et al., 2002; Fahlman and Kayar, 2003; Fahlman, 2017).

\section{GAS BUBBLE FORMATION IN AIR-BREATHING MARINE VERTEBRATES}

The formation of bubbles in human divers has been reported following saturation dives of less than $3 \mathrm{~m}$ of depth (Eckenhoff et al., 1990). Bubble formation is thought to originate from heterogenous micronuclei, and vary greatly within and between individuals, even following the same dive sequence (Ljubkovic et al., 2012; Papadopoulou et al., 2018). It is possible that individual variability in these micronuclei could be one reason for the variation in venous gas emboli (Katsenelson et al., 2009). Asymptomatic bubbles appear to be a regular occurrence in stranded dolphins (Dennison et al., 2012b), and in deepdiving species repeated exposure to microbubbles may result in cumulative dysbaric osteonecrosis (Moore and Early, 2004). While the supersaturation required to initiate bubble growth is certainly important, the level of supersaturation that causes symptomatic bubbles differs with animal size, most likely due to the allometric variation in metabolism and blood flow (Berghage et al., 1979; Fahlman, 2017). Thus, if risk of symptomatic gas emboli (DCS/GEP) varies with body mass, it is reasonable to suggest that larger marine mammals will be more susceptible as compared with smaller ones for the same level of supersaturation (Figure 3), but the overall blood and tissue $\mathrm{N}_{2}$ levels are likely to be lower in larger sized animals due to the longer $\tau_{\text {tiss } 1 / 2}$ in a larger animal. However, the blood and tissue tensions will ultimately depend on the previous dive sequence, metabolic rate, the level of blood flow, and the relationship between changes in alveolar and arterial gas exchange, i.e., pulmonary shunt, caused by alveolar compression, and depth (Kooyman and Sinnett, 1982; Fahlman et al., 2006, 2007; Hooker et al., 2009; McDonald and Ponganis, 2012).

\section{Scholander's Balloon/Pipe Model and Alveolar Compression}

In his seminal work, Per Scholander (1940) developed the idea that the rigid upper airways together with a flexible chest and alveolar space would result in alveolar compression and collapse as the ambient pressure increases with depth. This collapsible balloon and incompressible pipe (balloon-pipe model, Figure 2) would limit gas exchange at depth and thereby reduce $\mathrm{N}_{2}$ uptake during breath-hold dives (Scholander, 1940). To be a protective mechanism against excessive uptake of 


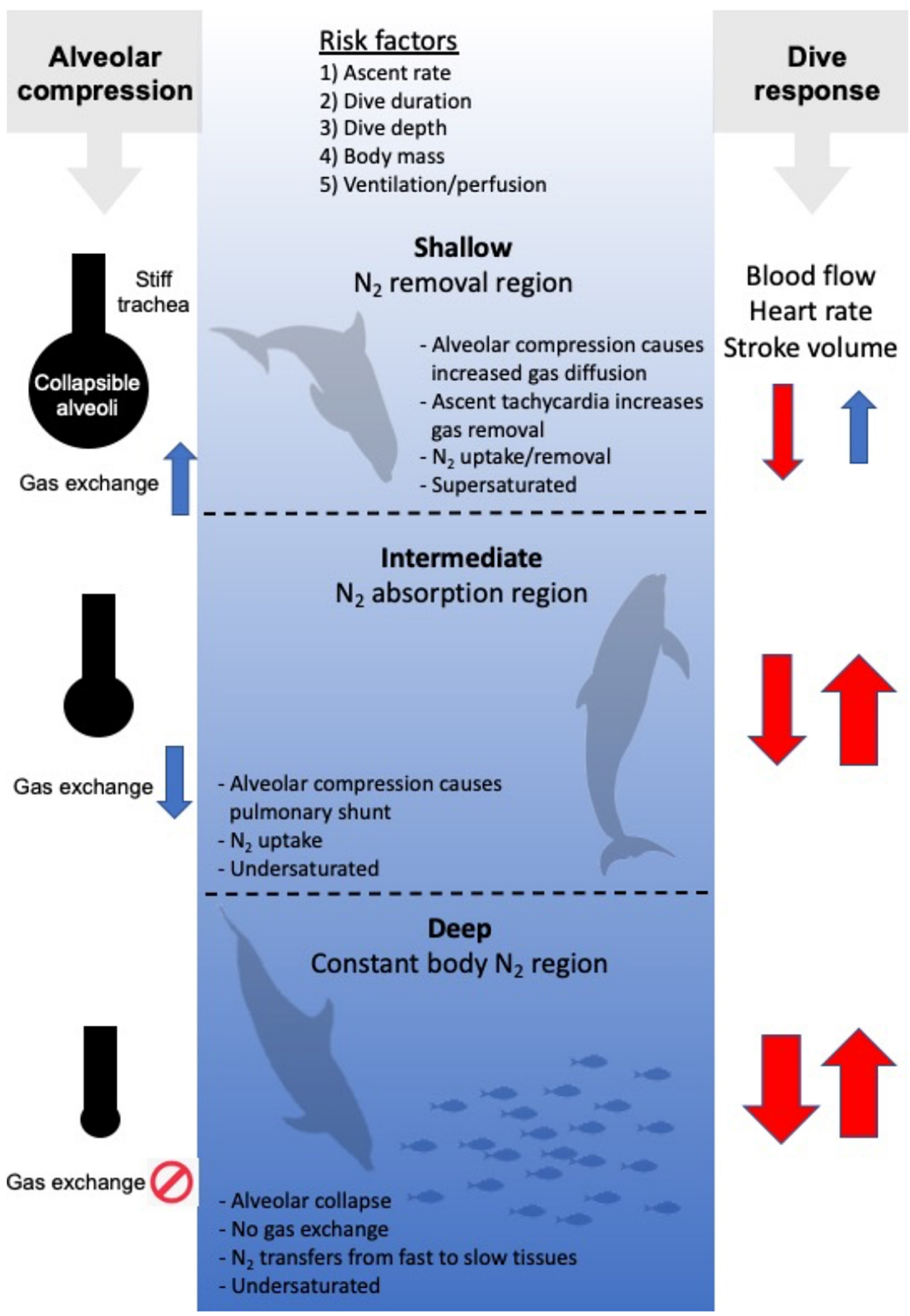

FIGURE 2 | Risk factors for gas bubble formation and Gas Emboli Pathology (GEP), and 3 hypothetical regions [Shallow (0- 30 m), Intermediate (30-200 m), and Deep (beyond $200 \mathrm{~m})$ ]. In the Shallow region, tissue and blood $\mathrm{PN}_{2}$ begins to exceed ambient $\mathrm{PN_{2 }}$, and $\mathrm{N}_{2}$ is removed. In the intermediate region, ambient $\mathrm{PN} \mathrm{N}_{2}$ exceeds tissue and blood $\mathrm{PN}_{2}$ and $\mathrm{N}_{2}$ is taken up until the alveoli collapse in the Deep region. Following collapse, $\mathrm{N}_{2}$ is being redistributed from fast tissues to slow tissues. On the left hand side, the balloon/pipe model proposed by Scholander (1940) is shown for how increasing dive depth causes alveolar compression and collapse. This initially causes an increase in the gas diffusion rate in the shallow region as the lung partial pressure increases. In the intermediate region the 
FIGURE 2 | Continued

compression of the alveoli results in an increasing shunt and reduced diffusion rate that eventually result in cessation as the alveoli collapse. On the right side the arrows illustrate how diving alters heart rate, stroke volume and cardiac output (the dive response). During descent (arrow down), the heart rate, stroke volume and cardiac output decreases (red color), with a greater reduction with increasing dive duration and depth (thickness of arrow). During ascent (arrow up), the dive response is maintained until the animal approaches the surface, where the heart rate, stroke volume and cardiac output begin to increase to prepare the animal to rapidly restore the $\mathrm{O}_{2}$ stores, and remove $\mathrm{CO}_{2}$ and $\mathrm{N}_{2}$.

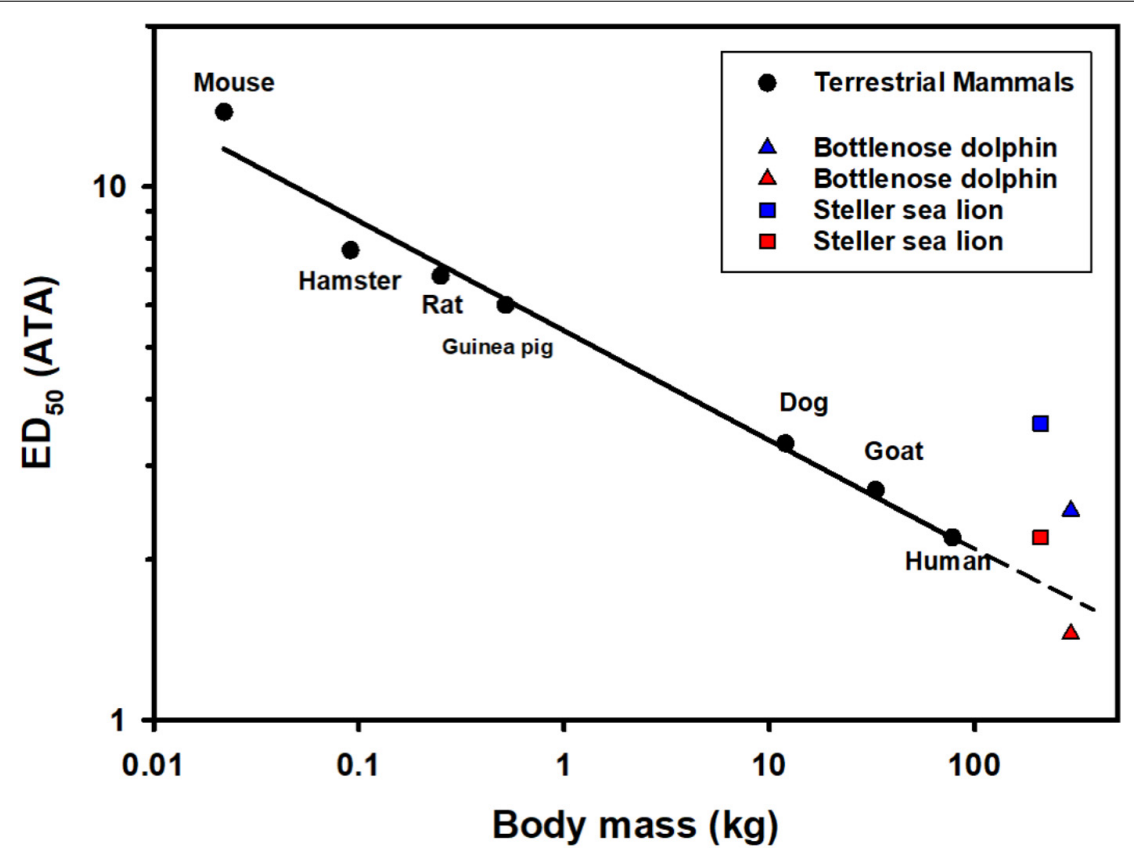

FIGURE 3 | The median $\mathrm{N}_{2}$ saturation pressure (ATA) causing $50 \%$ (ED 50 ) severe decompression sickness (DCS) in a range of terrestrial mammals following rapid decompression (Berghage et al., 1979; Fahlman, 2017; García-Párraga et al., 2018b). Also included are the estimated end-dive mixed venous N2 tension for the Steller sea lion (Hodanbosi et al., 2016) and bottlenose dolphin using a previously published gas dynamics models (Fahlman et al., 2006, 2009, 2018b; Hooker et al. 2009; Kvadsheim et al., 2012; Hodanbosi et al., 2016). Black circles are ED50 (saturation pressure giving 50\% DCS) for terrestrial mammals, the solid line indicates the best-fit regression $\log \mathrm{ED}_{50}=0.730-0.205 \log M_{\mathrm{b}}$. The triangles and squares are the estimated end-dive mixed venous $N_{2}$ tension for the dolphin $\left(M_{\mathrm{b}}=294 \mathrm{~kg}\right.$; Fahlman et al., 2018b) and Steller sea lion ( $M_{b}=210 \mathrm{~kg}$; Hodanbosi et al., 2016), respectively. The blue symbols represent model estimates with structural lung parameters from terrestrial mammals as presented previously (Bostrom et al., 2008), and the red with species-specific parameters (Hodanbosi et al., 2016; Fahlman et al., 2018b). The dolphin data represent the end-dive mixed venous $\mathrm{N}_{2}$ tension following a single dive to $140 \mathrm{~m}$, while sea lion 4 repeated dives to $40 \mathrm{~m}$.

$\mathrm{N}_{2}$ and gas bubble formation, the depth where the alveoli collapse and gas exchange ceases is important and has been the subject of a number of studies. Scholander's balloon-pipe model of the respiratory system suggested that the alveolar collapse depth in whales and seals [Northern bottlenose whale (Hyperoodon ampullatus), hooded seal, gray seal (Halichoerus grypus), fin whale (Balaenoptera physalus), harbor porpoise (Phocaena communis/phocaena)], would range from 30 to $210 \mathrm{~m}$ depending on the initial diving lung volume (Scholander, 1940).

The balloon-pipe model suggested that the alveolar collapse depth could be estimated from the relative volume of each of the parts of the respiratory system using Boyle's law (Scholander, 1940). Later, calculations showed that even if the upper airways did compress, there was movement of air from the alveoli into the upper airways as long as the conducting airways were stiffer as compared with the alveolar space (Denison and Kooyman, 1973). Two independent models were developed to estimate how the respiratory system behaves during breathhold dives in humans (Fitz-Clarke, 2009a) and air breathing marine vertebrates (Bostrom et al., 2008). These theoretical models suggested that compression of the respiratory system and increased partial pressure initially cause an increased diffusion rate. As depth increases, a pulmonary shunt develops that reduces the diffusion rate (Scholander, 1940; Bostrom et al., 2008). When the alveoli close and gas exchange ceases, the gas tensions in the systemic arteries will be the same as in the pulmonary artery, and there will be a drop in systemic arterial $\mathrm{PO}_{2}$ (Bostrom et al., 2008; Fahlman et al., 2009). Recent studies in the California sea lion (Zalophus californianus) provided empirical evidence for these theoretical results, and suggested that the alveolar collapse depth occurs at depths exceeding $200 \mathrm{~m}$ (McDonald and Ponganis, 2012, 2013). The theoretical modeling (Bostrom et al., 2008; Fahlman et al., 2009, 2018b; Hodanbosi et al., 2016), based on data from studies that defined the structural properties of the respiratory system (Denison et al., 1971; Denison and Kooyman, 1973; Leith, 1976; Piscitelli et al., 2010; Fahlman et al., 2011, 2014a, 2015, 2018a,c, 2020a,c; Moore C. et al., 2014; Fahlman and Madigan, 2016; Denk et al., 2020), agrees with these 
empirical estimates for alveolar collapse depths and cessation of gas exchange in the California sea lion, and also the elephant seal (Mirounga angustirostris), and Weddell seal (Leptonychotes weddellii) (Kooyman et al., 1972; Kooyman and Sinnett, 1982; Fahlman et al., 2009; Hodanbosi et al., 2016).

While theoretical models are limited by assumptions, they allow new hypotheses to be formulated that can be empirically tested. For example, these theoretical models suggest that the level of supersaturation depends on the alveolar collapse depth, the cardiac output, and blood flow distribution (Fahlman et al., 2006, 2009). Furthermore, improving model accuracy can help forecast the potential consequences of acute and chronic disturbances, and provide important information for conservation efforts for marine species.

\section{Assessing Risk of Gas Bubbles in Air-Breathing Marine Vertebrates}

With the development of bio-logging tools, the diving capabilities of air-breathing vertebrates are now being studied, and many species are able to perform deep and long dives without apparent GEP symptoms (Laidre et al., 2003; Miller et al., 2007; Robinson et al., 2012; Schorr et al., 2014; Fahlman et al., 2018b; Shearer et al., 2019; Quick et al., 2020). However, more remarkable still are the extensive foraging bouts of many diving mammals and birds (Miller et al., 2004; Aguilar Soto et al., 2008; Aoki et al., 2011; Robinson et al., 2012; Schorr et al., 2014; Fahlman et al., 2018c; Quick et al., 2020). Theoretical models agree with the suggestion made by Scholander (1940), that the repeated diving behavior with short surface intervals result in accumulation of blood and tissue of $\mathrm{N}_{2}$, with increasing risk for supersaturation, gas bubble formation, and GEP (Figure 1B; Fahlman et al., 2007; Hooker et al., 2009). A growing number of studies are concluding that air-breathing marine vertebrates may in fact experience symptomatic gas bubbles similar to those found in commercial human scuba divers (Jepson et al., 2003, 2005; Moore and Early, 2004; Moore et al., 2009; Van Bonn et al., 2011, 2013; Bernaldo de Quirós et al., 2012; Dennison et al., 2012b; GarcíaPárraga et al., 2014; Fernández et al., 2017). Gas bubbles have been found in both live and deceased specimens, and reports suggest that asymptomatic gas bubbles may be more common than formerly thought (Moore and Early, 2004; Van Bonn et al., 2011, 2013; Dennison et al., 2012b). However, one study was unable to detect gas bubbles using ultrasound in repeatedly diving bottlenose dolphins (Houser et al., 2010). It is possible that the number of repeated dives that the dolphins performed was not sufficient to allow detection of $\mathrm{N}_{2}$ levels, or could provide evidence that diving-adapted species have a mechanism that helps reduce the inert gas uptake (García-Párraga et al., 2018b; Fahlman et al., 2020b).

Modeling studies have shown that the level of gas exchange and cardiac output are the two variables that have the largest effect on gas dynamics (Section "Scholander's Balloon/Pipe Model and Alveolar Compression") (Fahlman et al., 2006, 2009). The pulmonary shunt that develops and reduces gas exchange with depth depends on the structural properties of the respiratory system (Bostrom et al., 2008; Fitz-Clarke, 2009a). Initial studies used parameters for the structural properties of the respiratory system from terrestrial mammals, resulting in model estimates that suggested that symptomatic gas bubbles should occur more than $50 \%$ of the time (Figure 3 blue symbols). Measurement of species-specific structural properties for the respiratory system in the sea lion and bottlenose dolphin for excised tissues (Denison et al., 1971; Denison and Kooyman, 1973; Kooyman and Sinnett, 1982; Fahlman et al., 2011, 2014a; Moore C. et al., 2014), in live animals under human care (Fahlman et al., 2015, 2019a,b, 2020c; Fahlman and Madigan, 2016), and in the wild (Hurley and Costa, 2001; Fahlman et al., 2008, 2013, 2018a,c; Hindle et al., 2010) have shown that both the anatomy and physiology of marine mammals help to minimize $\mathrm{N}_{2}$ exchange (Figure 3 red symbols).

\section{HOW TO AVOID GAS EMBOLIC PATHOLOGY (GEP)}

There are a number of alternatives for how breath-hold diving vertebrates avoid symptomatic GEP. One is to avoid uptake of $\mathrm{N}_{2}$, and there are a few possible ways to minimize or reduce $\mathrm{N}_{2}$ uptake (section "Avoiding $\mathrm{N}_{2}$ Uptake"). (1) The first is to dive with a low diving lung volume which reduces the total $\mathrm{N}_{2}$ that can be absorbed (section "Diving With a Low Lung Volume"), or (2) a respiratory system that allows for the alveoli to be gas-free at shallow depth [alveolar collapse (section "Alveolar Collapse and the Importance of Managing Gas Exchange")], or (3) cardiovascular management of pulmonary and systemic blood flow to minimize $\mathrm{N}_{2}$ uptake (section "The Effect of Variation in Cardiac Output and Blood Flow Distribution in GEP Risk"). The selective gas exchange hypothesis proposes a combination of 2 and 3 where selective management of gas exchange is made possible by matching pulmonary blood flow to non-ventilated (collapsed) regions of the lung, which allows selective exchange of gases (Figure 4, section “The Selective Gas Exchange Hypothesis”). In the case marine mammals accumulate $\mathrm{N}_{2}$ during repeated dives, the second option would be to manage the dissolved $\mathrm{N}_{2}$ to reduce the supersaturation (section "Ways to Manage Blood and Tissue $\mathrm{N}_{2}$ "). It is also possible that air-breathing marine vertebrates have adaptations that reduce the effect of the gas bubbles (Scholander, 1940; Kooyman, 1973; Leith, 1989; section "Adaptations That Help Reduce the Effect of Bubbles; Anatomical or Immunological Adaptations”).

\section{Avoiding $\mathrm{N}_{2}$ Uptake Diving With a Low Lung Volume}

It is generally thought that many species of seals reduce the diving lung volume at the start of a dive, while cetaceans and sea lions generally dive on inhalation (Ponganis, 2011; Piscitelli et al., 2013; Fahlman et al., 2017b). Whether an animal dives on inhalation or exhalation may not be as important as the diving lung volume (Fahlman et al., 2009). While this has been difficult to study in free-ranging species, development of biologging tools has provided some recent estimates. For example, fur seals appear to exhale during the ascent (Hooker et al., 2005). It was suggested that ascent exhalation is a behavioral strategy to sustain the pulmonary shunt as the animal approaches 


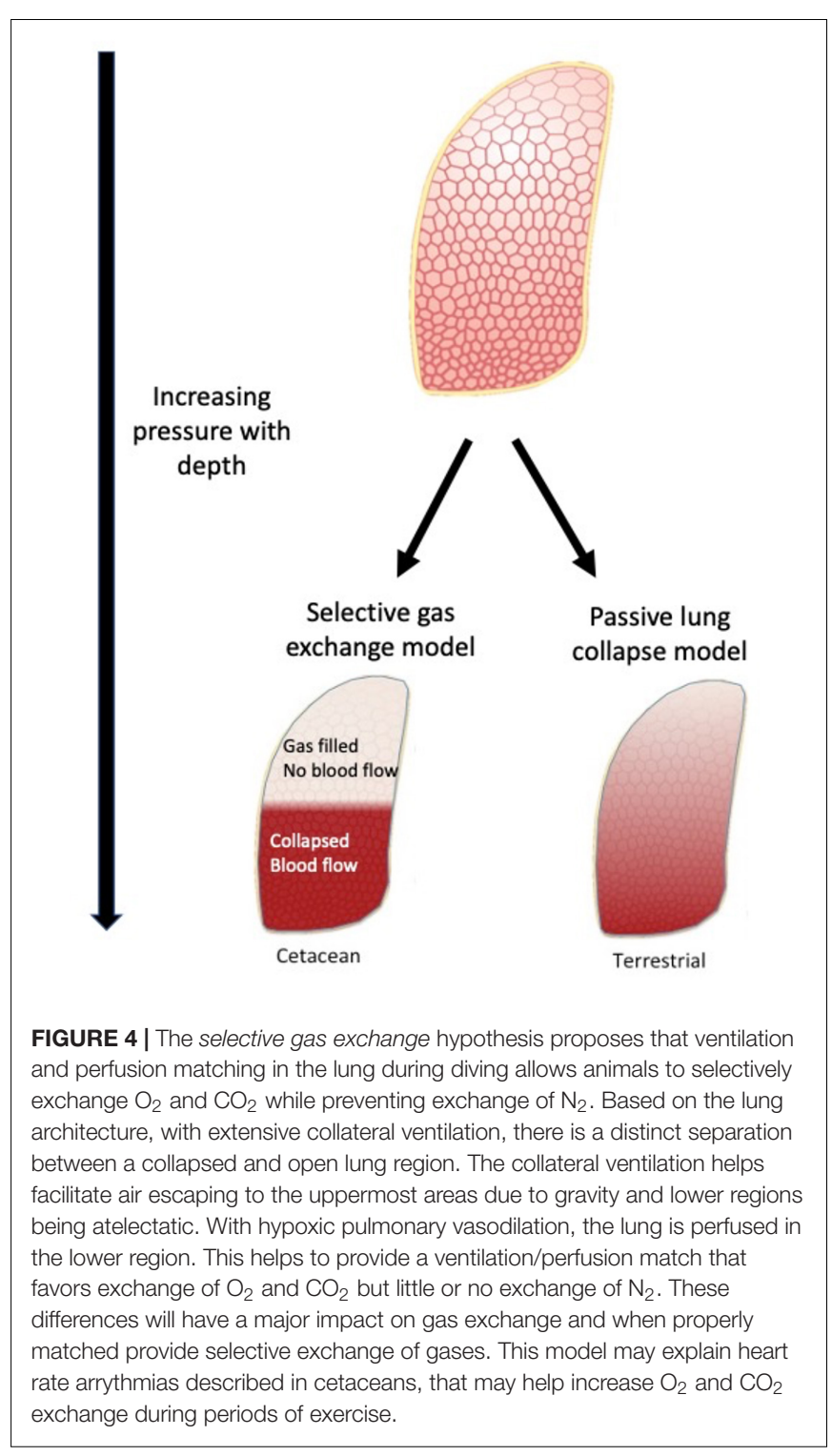

the surface and the pulmonary gas expands, which would help prevent gas exchange and shallow water blackout (Hooker et al., 2005; Bostrom et al., 2008). In cetaceans, and diving birds, glide portions during ascents have provided a method to estimate the diving lung volume from the changes in buoyancy as the lungs are expanding (Sato et al., 2003, 2011; Miller et al., 2004, 2016; Aoki et al., 2017; Narazaki et al., 2018). However, recent theoretical modeling, which accounted for the large variation in blood and tissue gas solubility between $\mathrm{O}_{2}, \mathrm{CO}_{2}$, and $\mathrm{N}_{2}$, suggested that the pulmonary mass-balance of gas changes throughout the dive. For this reason, the diving lung volume at the same depth will not be the same at the beginning and end of the dive (Fahlman et al., 2020d). Using these results and those from past studies, it was suggested that it is likely that the diving lung volume in cetaceans could be close to the estimated total lung capacity (Kooyman, 1973; Fahlman et al., 2011, 2020d). Thus, future studies to better estimate diving lung volume may be warranted as it affects the risk of GEP (Fahlman et al., 2009;
Fitz-Clarke, 2009a,b). In both humans and dolphins, respiratory sinus arrythmia has been shown to be one possible indirect method to estimate breathing frequency and tidal volume (Hirsch and Bishop, 1981; Cauture et al., 2019). Phonospirometry, or breath sound recording, is another method that has been used to determine breathing frequency and respiratory flow (Sumich, 2001; Sumich and May, 2009; Rojano-Doñate et al., 2018), and may provide future capabilities to estimate diving lung volume in free-swimming species. Such developments to directly measure physiology in free-ranging animals, physio-logging, will enable improved understanding of the physiological plasticity of marine vertebrates, and how pressure affects gas exchange.

\section{Alveolar Collapse and the Importance of Managing Gas Exchange}

During the dive, the pressure will compress the alveoli and alter the pulmonary shunt (Figure 2; Kooyman and Sinnett, 1982; Bostrom et al., 2008; Fahlman et al., 2009; Fitz-Clarke, 2009a; McDonald and Ponganis, 2012). For passive alveolar collapse, the structural properties of the respiratory system, and the diving lung volume will affect the alveolar collapse depth (Kooyman and Sinnett, 1982; Bostrom et al., 2008; Fahlman et al., 2009; Fitz-Clarke, 2009a; McDonald and Ponganis, 2012). A number of studies have defined the structural properties from excised tissues, anesthetized and awake animals (Denison and Kooyman, 1973; Tarasoff and Kooyman, 1973; Leith, 1976; Kooyman and Sinnett, 1979; Cozzi et al., 2005; Piscitelli et al., 2010; Bagnoli et al., 2011; Davenport et al., 2013, 2014; Fahlman et al., 2014a, 2015, 2017b, 2018c; Moore C. et al., 2014; Fahlman and Madigan, 2016). In general, both lung and chest compliance, measures of structural compressibility, are greater in marine as compared with terrestrial mammals (Olsen et al., 1969; Denison et al., 1971; Denison and Kooyman, 1973; Tarasoff and Kooyman, 1973; Leith, 1976, 1989; Kooyman and Sinnett, 1979; Cozzi et al., 2005; Piscitelli et al., 2010; Bagnoli et al., 2011; Fahlman et al., 2011, 2014a, 2017b, 2018b; Davenport et al., 2013; Moore C. et al., 2014; Denk et al., 2020). One study looking at the anatomy and structural properties of the airways suggested that the compliance of the trachea was related to dive behavior (Moore C. et al., 2014). However, another study reported that there was no difference in lung compliance in shallow as compared with deep-diving bottlenose dolphins, possibly suggesting that passive alveolar collapse is not sufficient to protect against diving related problems (Fahlman et al., 2018c). In addition, in cetaceans, the intraluminal transitional epithelia have venous vessels that have been proposed to be able to engorge with blood (Cozzi et al., 2005; Costidis and Rommel, 2012). Such engorgement may dynamically alter the observed compliance during the dive, making predictions of alveolar compression difficult to make without a better understanding of the anatomy and function of this tissue. Thus, there may be large differences in functional compliance among species, which in turn will affect the pulmonary shunt, and thereby the level of gas exchange.

\section{The Effect of Variation in Cardiac Output and Blood Flow Distribution in GEP Risk}

Inert gas uptake and removal is perfusion-limited, i.e., it depends on cardiac output and not minute ventilation, and therefore the 
cardiovascular changes seen during diving significantly alter inert gas dynamics (Farhi, 1967; Farhi and Yokoyama, 1967). Some have suggested that the reduced heart rate during the dive helps reduce inert gas uptake, while the tachycardia during ascent improves removal (Irving, 1935; Scholander, 1940; Berkson, 1967; Ponganis et al., 1999; Fahlman et al., 2007). Coupling physiology with behavior may be an important strategy to reduce uptake and enhance removal (see section "Managing Accumulated $\mathrm{N}_{2}$ to Reduce Supersaturation; Coupling Behavior and Physiology"), and conditioned variation in heart rate has been shown in several species, suggesting that they may have control over blood flow that helps manage gas exchange (Elsner, 1965; Elsner et al., 1966; Jones et al., 1973; Casson and Ronald, 1975; Ridgway et al., 1975; Elmegaard et al., 2016; Fahlman et al., 2020b).

\section{The Selective Gas Exchange Hypothesis}

In 2018, based on past studies both in mammals and reptiles (section "From Model to Tests With Free-Ranging Animals"), the selective gas exchange hypothesis was introduced (Figure 4; García-Párraga et al., 2018b). This hypothesis suggested that in addition to passive lung compression and alveolar collapse, an active mechanism that helps alter the perfusion and ventilation matching during diving would allow breath-hold divers to selectively exchange $\mathrm{O}_{2}$ and $\mathrm{CO}_{2}$ during diving, while at the same time minimizing exchange of $\mathrm{N}_{2}$. This mechanism relied on the large differences in gas solubility between $\mathrm{O}_{2}, \mathrm{CO}_{2}$, and $\mathrm{N}_{2}$, and on conditioned capacity to selectively alter pulmonary blood flow to atelactic regions during diving. This hypothesis also explains how failure of this mechanism, during periods of excessive stress, could result in increased exchange of $\mathrm{N}_{2}$ which could result in GEP and strandings (García-Párraga et al., 2018b; Fahlman et al., 2020b).

\section{Ways to Manage Blood and Tissue $\mathrm{N}_{2}$}

Where $\mathrm{N}_{2}$ is taken up, there are a number of physiological adaptations that may help manage the inert gas burden, which include: (a) tissue and blood $\mathrm{N}_{2}$ solubility and a special $\mathrm{N}_{2}$ absorbing tissue, and (b) coupled physiology and behavior to reduce the formation of gas bubbles in case the blood and tissue $\mathrm{N}_{2}$ tension is elevated.

Many air breathing vertebrates that dive have extended periods when they perform repeated breath-holds which are separated by relatively short surface intervals. During these dive bouts, the mixed venous blood and tissue $\mathrm{N}_{2}$ levels, a measure of the whole body $\mathrm{N}_{2}$ levels, tend to slowly increase as the slow tissues accumulate $\mathrm{N}_{2}$ during repeated dives (Houser et al., 2001; Fahlman et al., 2006, 2007; Zimmer and Tyack, 2007; Fitz-Clarke, 2009b; Hooker et al., 2009). As mentioned earlier (section "Uptake, and Removal of $\mathrm{N}_{2}$, and How Bubbles Form in Scuba and Breath-Hold Divers"), the dynamics of $\mathrm{N}_{2}$ uptake and removal depend on the total tissue volume, the local blood flow rate, and the solubility of $\mathrm{N}_{2}$ (Fahlman et al., 2006). The blood and tissue solubility of $\mathrm{N}_{2}$ is very low, but similar in seals and humans (Kooyman, 1973). The $\mathrm{N}_{2}$ solubility is approximately 5 times higher in lipids as compared to water and blood (Kooyman, 1973; Weathersby and Homer, 1980; Koopman and Westgate, 2012;
Gabler-Smith et al., 2020), but the solubility differs considerably between lipid types where some deep diving species with a higher proportion of waxy esters have $73 \%$ higher $\mathrm{N}_{2}$ solubility in blubber (Koopman and Westgate, 2012). In addition, not only does the $\tau_{\text {tiss } 1 / 2}$ differ among tissues due to varying solubility and tissue volume, but it varies throughout the dive due to the changes in cardiac output, blood flow distribution, and the pulmonary shunt (Fahlman et al., 2006, 2007, 2019b; Zimmer and Tyack, 2007; Fitz-Clarke, 2009b).

Most diving mammals have large amounts of subcutaneous fat that reduces heat loss and acts as an energy reservoir during extended periods without food (Iverson, 2009). The higher $\mathrm{N}_{2}$ solubility, and the low blood flow in blubber results in a long $\tau_{\text {tiss } 1 / 2}$ for adipose tissue (Fahlman et al., 2006, 2007; Hooker et al., 2009). The overall effect is that a "fast" tissue (Figure 1, $\tau_{5}$ ), with high perfusion and low $\mathrm{N}_{2}$ solubility, experiences high $\mathrm{N}_{2}$ tensions during the dive, but these are rapidly cleared and these tissues seldom experience excessive supersaturations that may result in gas bubble formation (Fahlman et al., 2007, 2009; Zimmer and Tyack, 2007; Hooker et al., 2009). A "slow" tissue, like blubber (Figure 1, $\tau_{50}$ ), on the other hand, slowly accumulates $\mathrm{N}_{2}$ with repeated dives until a steady-state is reached at which time the tissue $\mathrm{N}_{2}$ levels are more or less constant throughout the dive bout (Fahlman et al., 2007, 2009; Zimmer and Tyack, 2007; Hooker et al., 2009). Thus, blubber may initially help "absorb" $\mathrm{N}_{2}$ and may help reduce bubble formation during deep and short dives (Behnke et al., 1935; Fahlman et al., 2007). However, during a long dive bout the blubber $\mathrm{PN}_{2}$ may continue to increase and eventually become a liability (Fahlman et al., 2007). The dynamics of $\mathrm{N}_{2}$ are clearly complex and depend on a number of physiological factors, many that are poorly investigated, especially across species.

\section{Managing Accumulated $\mathrm{N}_{2}$ to Reduce Supersaturation; Coupling Behavior and Physiology}

Behavior coupled with physiology may provide alternative and complementary means to reduce the inert gas burden. Both diving birds and mammals reduce their ascent rate when approaching the surface (Hooker and Baird, 1999; Sato et al., 2004; Tyack et al., 2006), and some also have been shown to couple this with an increase in heart rate (Andrews et al., 1997; Froget et al., 2004), which will help reduce the end-dive blood and tissue $\mathrm{PN}_{2}$ (Fahlman et al., 2006, 2007). A theoretical study estimated that this physiological coupling to behavior close to the surface could reduce the inert gas burden by up to $45 \%$ before surfacing (Fahlman et al., 2006). However, the results also suggested that the reduction in blood flow may not always be protective, but depends on the $\tau_{\text {tiss } 1 / 2}$, and maximum enddive $\mathrm{PN}_{2}$ levels for all tissues were observed when $\tau_{\text {tiss } 1 / 2}$ was similar to the average dive duration (Fahlman et al., 2007). Thus, to minimize tissue $\mathrm{PN}_{2}$, each tissue should avoid blood flow rates that result in a $\tau_{\text {tiss } 1 / 2}$ close to the dive duration. However, perfusion also depends on the necessity to remove $\mathrm{CO}_{2}$ and supply $\mathrm{O}_{2}$. The diving cardiac output and blood flow distribution is a complex trade-off between the need to reduce the end-dive tissue and blood $\mathrm{PN}_{2}$, while at the same time supply sufficient $\mathrm{O}_{2}$ 


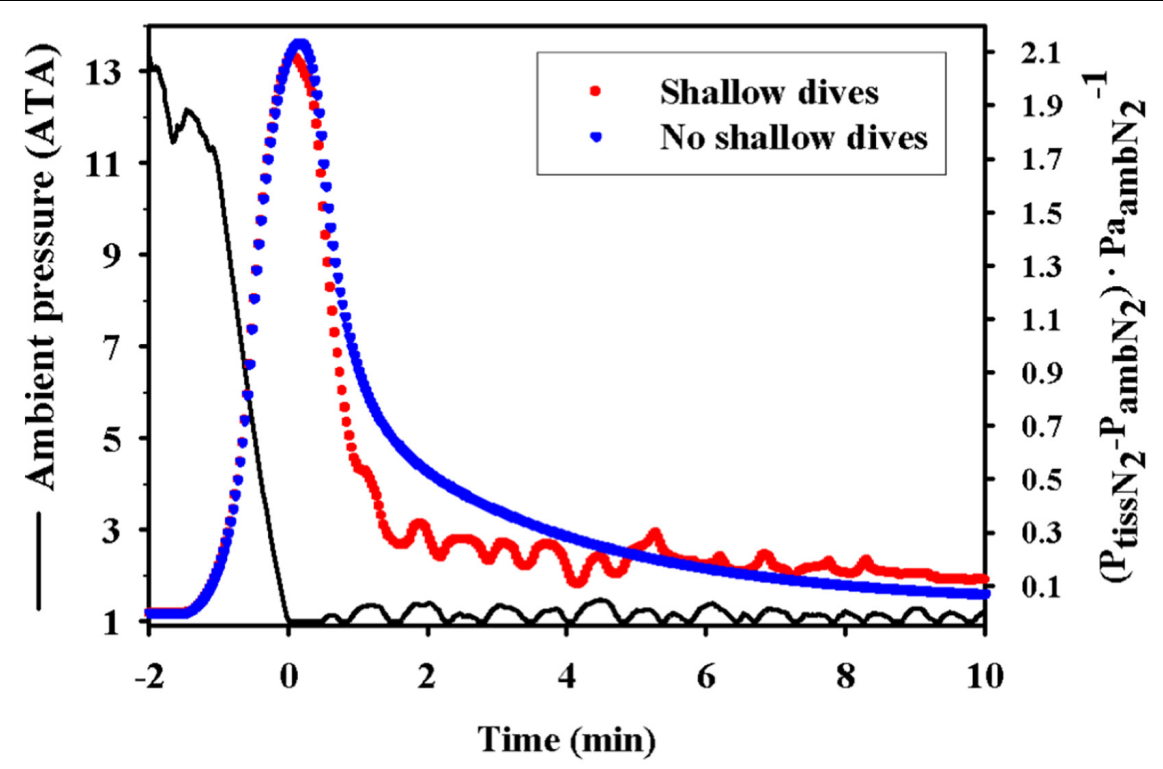

FIGURE 5 | Theoretical effect showing how the short and shallow dive following a series of repeated foraging dives (dive bout) helps to reduce the supersaturation in a king penguin (Aptenodytes patagonicus). The figure shows ambient pressure (ATA) and estimated mixed venous supersaturation [(PN 2 venous $\left.\left.-\mathrm{PN} \mathrm{N}_{2 a m b}\right) \cdot \mathrm{P} \mathrm{N}_{2 a m b}{ }^{-1}\right]$ for short and shallow dives (red dots) or no shallow diving (blue dots) follow a dive bout. The figure is reproduced from Fahlman et al. (2007).

for aerobic metabolism and to remove $\mathrm{CO}_{2}$ to avoid build up and disturbing the acid-base balance.

Another behavioral feature that may help reduce supersaturation and the risk of gas bubble formation is the short and shallow surface dives that are observed between deep dives or at the end of extended dive bouts in both diving birds and marine mammals (Figure 5; Fahlman et al., 2007, 2018b). These shallow dives have to be to a depth that allows removal of $\mathrm{N}_{2}$, and therefore not deeper than the tissue and mixed venous $\mathrm{PN}_{2}$, or generally not deeper than $30 \mathrm{~m}$. Interestingly, in king penguins these decompression dives are deepest at the end of a dive bout and subsequently become more shallow (Fahlman et al., 2007). Unfortunately, many current and past ecological studies that use satellite-linked time-depth-recorders to study marine species only consider dives deeper than $50 \mathrm{~m}$ to be of interest (and/or to prolong tag life through reducing data transmissions), so these details are often lost. However, with technological improvements we are likely going to be able to get high resolution records of surface activity from a broader range of species to provide more empirical data to explore this suggestion.

\section{Adaptations That Help Reduce the Effect of Bubbles; Anatomical or Immunological Adaptations}

It is also possible that marine mammals have anatomical or biochemical adaptations that help prevent trauma, or secondary effects from the presence of bubbles. This could include anatomical structures like rete mirabilia, that act as a gas bubble trap, or an immune response that does not respond to circulating gas bubbles.

If marine mammals experience repeated exposure to asymptomatic microbubbles it is conceivable that these species have evolved protective mechanisms that deal with these bubbles. One example is the thoracic and vertebral arterial retia mirabilia that is present in several diving species, e.g., bottlenose dolphin, narwhal (Monodon monoceros), sperm whale (Physeter macrocephalus), beluga (Delphinapterus leucas), and harbor porpoise (Vogl and Fisher, 1982; Melnikov, 1997). These highly tortuous vascular deltas are embedded in adipose tissue and may provide a protective structure that traps and dissolves microbubbles before reaching the brain (Blix et al., 2013). However, it is not only the direct effect of bubbles that may cause symptoms, but symptoms may also be due to secondary effects in response to invading bubbles.

Bubble formation is believed to be the crucial event in the etiology of DCS/GEP, where vascular bubbles may impair blood flow. Recompression treatment would shrink the bubbles by driving some of the gas back into solution in tissue fluids, and help to improve flow and oxygenation, minimize secondary effects, and also reduce the effect of bubbles that may form in tissues. Growing evidence suggests that a majority of symptoms are attributable to secondary effects induced by non-obstructive bubbles (Bove, 1982). It has become apparent that some of the symptoms are similar to those of other disease states (Ward et al., 1987, 1990; Kayar et al., 1997), with a recurring theme of an acute, non-specific inflammatory response initiated by the bubbles (Bove, 1982). Hematological studies have given birth to the idea that the circulating bubbles might induce activation of the clotting cascade, leading to the formation of a free-floating fibrin clot that would cause an embolus (Philp, 1974; Philp et al., 1972, 1979; Boussuges et al., 1998). In addition, activation of an acute immune response (Ward et al., 1990; Stevens et al., 1993; Yamashita et al., 1994; Kayar et al., 1997; Ersson et al., 1998), and the complementary cascade (Ward et al., 1986, 1987, 1990; Stevens et al., 1993), have been proposed to be involved in the 
development of DCS. These effects may help explain some of the variability in DCS susceptibility among individuals and why symptoms may develop several hours after they return to the surface (Temple et al., 1999). Nevertheless, it seems that the level of supersaturation is the primary factor that triggers DCS, both in terrestrial and marine vertebrates (Berghage et al., 1979; Lillo et al., 2002; Fitz-Clarke, 2009b; Bernaldo de Quirós et al., 2012; Fahlman, 2017; Fahlman et al., 2017a).

Could marine mammals have immunological, biochemical or molecular adaptations that allow them to be less prone to gas bubbles? It was shown that bottlenose dolphins and killer whales (Orcinus orca) both lack the Hageman factor (factor $\mathrm{XII}$ ), one of the components in the clotting cascade, resulting in longer clotting duration (Robinson et al., 1969). This could be an adaptation for the blood to be less reactive toward circulating microbubbles. In addition, recent work on the immune function of blood cells in the beluga, has shown that Interleukin 2 receptor, monocytes and granulocytes respond differently to hyperbaric exposure as compared with human cells (Thompson and Romano, 2015, 2016, 2019). In another study with harbor seals (Phoca vitulina), gray seals (Halichoerus grypus), and harp seals (Phoca groenlandica), it was shown that immune and blood cell types respond differently to pressure and dive duration and that these responses are altered in sick animals (Thompson and Romano, 2019). Work on northern elephant seals, and Weddell seals suggests that there are anti-inflammatory properties in the blood in these species that may help prevent an almost continuous inflammatory response during repeated bouts of hypoxia during each repeated dive (Bagchi et al., 2018).

Recent work clearly shows that when stressed or disturbed, the normal physiological mechanism that helps breath-hold diving marine vertebrates minimize the risk of gas bubble disease fails (Jepson et al., 2003; Fernandez et al., 2005; Moore et al., 2009; Van Bonn et al., 2011, 2013; García-Párraga et al., 2014, 2018a; Fahlman et al., 2017a; Fernández et al., 2017; Bernaldo de Quirós et al., 2019; Parga et al., 2020). It is possible that the gas bubbles seen in stranded cetaceans and sea lions are caused by a multi-factorial etiology, and it is unclear how anthropogenic changes to the environment or acute stress affect different species. Since the turn of the century, we have seen escalating changes in the environment, with increasing human use of the ocean. To be able to avoid mass-extinction of marine mammals, there is an urgent need to improve our understanding of how physiology may limit survival. This is one of many reasons why long-term studies provide a vital place in conservation research as a platform to understand temporal change in environmental health.

\section{FROM MODEL TO TESTS WITH FREE-RANGING ANIMALS}

In 2012, a project was initiated that aimed to determine if MPs are a useful biomarker of decompression stress in marine mammals. This project aimed at measuring blood MP levels in healthy, wild bottlenose dolphins during capturerelease operations, and contrasting these with levels in stranded cetaceans from Cape Cod. Blood MP levels in stranded common dolphins (Delphinus delphis), Atlantic white-sided dolphins (Lagenorhynchus acutus), and harbor porpoises were significantly different from those of shallow-diving (Sarasota), deep-diving (Bermuda) bottlenose dolphins, or bottlenose dolphins housed in managed care (Moore M. J. et al., 2014; Moore et al., 2015). While it is possible that this may reflect differences between species, it is more likely that the consistently higher blood levels of small MPs and lower concentrations of large MPs in the stranded dolphins as compared with healthy wild animals reflect differences in physiological status, possibly related to decompression stress and GEP. This suggestion is based on the fact that $95 \%$ of livestranded dolphins $(n=22)$ scanned with B-mode ultrasound showed evidence of gas bubbles in the kidneys and hepatic portal vasculature, while none of the shallow-diving healthy wild dolphins showed any $(n=58)$ evidence of gas bubbles (Dennison et al., 2012b). It was suggested that the repetitive diving of healthy wild animals helps with recompression and to reduce gas bubble formation, unlike the situation in a stranded dolphin where the bubbles may be retained (Dennison et al., 2012b). While the results from the studies on blood MP levels are equivocal, this biomarker might serve as a diagnostic tool for stranding events that appears to reflect animals with circulating gas bubbles.

The ability to perform physiological measurements on wild dolphins also allowed studies on the respiratory function and lung mechanics in both shallow- and deep-diving bottlenose dolphins (Fahlman et al., 2018a,c). These data were important for testing the hypothesis formulated by Scholander (1940), that lung compression and alveolar collapse provides protection against GEP. If Scholander's hypothesis was true, we would expect to see differences in lung mechanics in deeper diving animals as compared with those making shallower dives (Bostrom et al., 2008; Fahlman et al., 2009). Over a number of field seasons data were collected on resting metabolic rate, and lung mechanics and showed that neither the resting metabolic rate, nor the lung compliance were different in free-ranging shallow- or deepdiving dolphins, and these were also similar to the results for dolphins in managed care (van der Hoop et al., 2014; Fahlman et al., 2015, 2018a,b,c; Pedersen et al., 2020). Revised modeling results using the empirical results from live dolphins showed estimated blood and tissue $\mathrm{N}_{2}$ levels that were lower (Figure 3, compare blue and red symbols), but passive collapse still did not explain why cetaceans do not experience a significant number of GEP events. These results allowed us to formulate the Selective Gas Exchange hypothesis (see section "The Selective Gas Exchange Hypothesis"), where the level of gas exchange is not just assumed to be a process that passively changes due to alveolar compression, but an active cardiorespiratory mechanism that allow selective gas exchange throughout the dive (GarcíaPárraga et al., 2018b) and studies are underway to help test the validity of the assumptions of this hypothesis, e.g., the heart rate response during diving depends on the anticipation of the dive (Fahlman et al., 2020b).

\section{SUMMARY}

While GEP in marine mammals is still controversial, it has been clearly shown in by-caught sea turtles where the severity 
of gas bubble score correlates with dive depth (García-Párraga et al., 2014; Fahlman et al., 2017a). The selective gas exchange hypothesis provides a mechanistic framework from which the variability in diving physiology and behavior can explain the risk of GEP, and that can be empirically tested. With the development of new physio-logging tools, the ability to better understand the physiological responses during diving will be enhanced. For such studies, opportunities to study wild animals where archival physio-logging tools can be recovered are likely to provide crucial data to understand the physiological responses to diving and how stress or disturbance alter this ability. In addition, the ability to study the physiological species differences within shallowand deep-diving dolphins provides an important baseline to understand physiological plasticity. Such studies are likely to be crucial for conservation efforts of these marine megafauna.

\section{AUTHOR CONTRIBUTIONS}

AF wrote the first draft of the review. All authors listed have made a substantial, direct and intellectual contribution to the work, and approved it for publication.

\section{REFERENCES}

Aguilar Soto, N., Johnson, M. P., Madsen, P. T., Díaz, F., Domínguez, I., Brito, A., et al. (2008). Cheetahs of the deep sea: deep foraging sprints in shortfinned pilot whales off Tenerife (Canary Islands). J. Animal Ecol. 77, 936-47. doi: 10.1111/j.1365-2656.2008.01393.x

Andrews, R. D., Jones, D. R., Williams, J. D., Thorson, P. H., Oliver, G. W., Costa, D. P., et al. (1997). Heart rates of northern elephant seals diving at sea and resting on the beach. J. Exp. Biol. 200, 2083-2095.

Aoki, K., Sato, K., Isojunno, S., Narazaki, T., and Miller, P. J. O. (2017). High diving metabolic rate indicated by high-speed transit to depth in negatively buoyant long-finned pilot whales. J. Exp. Biol. 220, 3802-3811. doi: 10.1242/jeb.158287

Aoki, K., Watanabe, Y. Y., Crocker, D. E., Robinson, P. W., Biuw, M., Costa, D. P., et al. (2011). Northern elephant seals adjust gliding and stroking patterns with changes in buoyancy: validation of at-sea metrics of body density. J. Exp. Biol. 214, 2973-2987. doi: 10.1242/jeb.055137

Bagchi, A., Batten, A. J., Levin, M., Allen, K. N., Fitzgerald, M. L., Hückstädt, L. A., et al. (2018). Intrinsic anti-inflammatory properties in the serum of two species of deep-diving seal. J. Exp. Biol. 221(Pt 13):jeb178491. doi: 10.1242/jeb.178491

Bagnoli, P., Cozzi, B., Zaffora, A., Acocella, F., Fumero, R., and Costantino, M. L. (2011). Experimantal and computational biomechanical characterization of the tracheo-bronchial tree of the Bottlenose dolphin (Tursiops truncatus). J. Biomechan. 44, 1040-1045. doi: 10.1016/j.jbiomech.2011.02.005

Behnke, A. R. (1951). "Decompression sickness following exposure to high pressures," in Decompression Sickness, ed. J. F. Fulton (Philadelphia: Philadephia Saunders), 53-89. doi: 10.1007/978-3-662-02409-6_4

Behnke, A. R., Thomson, R. M., and Shaw, L. A. (1935). The rate of elimination of dissolved nitrogen in man in relation to the fat and water content of the body. Am. J. Physiol. 114, 137-146. doi: 10.1152/ajplegacy.1935.114.1.137

Berghage, T. E., David, T. D., and Dyson, C. V. (1979). Species differences in decompression. Undersea Biomed. Res. 6, 1-13.

Berghage, T. E., Woolley, J. M., and Keating, L. J. (1974). The probabilistic nature of decompression sickness. Undersea Biomed. Res. 1, 189-196.

Berkson, H. (1967). Physiological adjustments to deep diving in the pacific green turtle (Chelonia mydas agassizii). Comparat. Biochem. Physiol. 21, 507-524. doi: 10.1016/0010-406x(67)90448-3

Bernaldo, de Quirós, Y., Fernandez, A., Baird, R. W., Brownell, R. L., Aguilar, et al. (2019). Advances in research on the impacts of anti-submarine sonar on beaked whales. Proc. R Soc. B: Biol. Sci. 286:20182533. doi: 10.1098/rspb.2018.2533

\section{FUNDING}

Many of the studies that have resulted in the data in this review, and that have been integral to develop the selective gas exchange hypothesis have been funded by the Office of Naval Research (ONR Awards \# N000141010159, N000141613088, N000141410563, N000140811220, and ONR YIP Award \#N000141410563), and Dolphin Quest. The authors declare that Dolphin Quest was not involved in the study design, collection, analysis, interpretation of data, the writing of this article or the decision to submit it for publication.

\section{ACKNOWLEDGMENTS}

We are grateful to all staff and colleagues who have made all these studies possible, and in particular the staff, students, and trained volunteers of the Chicago Zoological Society's Sarasota Dolphin Research Program. We would like to thank Alicia Borque-Espinosa for all her help with making the figures. A special thank you to Daniel García-Párraga for his contribution to the development of the Selective Gas Exchange Hypothesis.

Bernaldo, de Quirós, Y., Gonzales-Diaz, O., Arbelo, M., Sierra, E., Sacchini, S., et al. (2012). Decompression versus decomposition: distribution, quantity and gas composition of bubbles in stranded marine mammals. Front. Physiol. 3:177. doi: $10.3389 /$ fphys.2012.00177

Blix, A. S., Walløe, L., and Messelt, E. B. (2013). On how whales avoid decompression sickness and why they sometimes strand. J. Exp. Biol. 216, 3385-3387. doi: 10.1242/jeb.087577

Bostrom, B. L., Fahlman, A., and Jones, D. R. (2008). Tracheal compression delays alveolar collapse during deep diving in marine mammals. Respiratory Physiol. Neurobiol. 161, 298-305. doi: 10.1016/j.resp.2008.03.003

Boussuges, A., Succo, E., Juhan-Vague, I., and Sainty, J. M. (1998). Activation of coagulation in decompression illness. Aviat. Space Environ. Med. 69, 129-132.

Boutilier, R. G., Reed, J. Z., and Fedak, M. A. (2001). Unsteady-state gas exchange and storage in diving marine mammals: the harbor porpoise and gray seal. Am. J. Physiol. 281, R490-R494.

Bove, A. A. (1982). The basis for drug therapy in decompression sickness. Undersea Biomed. Res. 9, 91-111.

Boycott, A. E., Damant, G. C. C., and Haldane, J. S. (1908). The prevention of decompression-air illness. J. Hygiene 8, 342-443.

Broome, J. R., Dutka, A. J., and Mcnamee, G. A. (1995). Exercise conditioning reduces the risk of neurologic decompression illness in swine. Undersea Hyperbaric Med. 22, 73-85.

Broome, J. R., Pearson, R. R., and Dutka, A. J. (1994). Failure to prevent decompression illness in rats by pretreatment with a soluble complement receptor. Undersea Hyperbaric Med. 21, 287-295.

Casson, D. M., and Ronald, K. (1975). The harp seal, Pagophilus groenlandicus (Erxleben, 1777)-XIV. cardiac arrythmias. Comparat. Biochem. Physiol. Part A: Physiol. 50, 307-314. doi: 10.1016/0300-9629(75)90018-3

Cauture, F., Sterbaboatwright, B., Miedler, S., Rocho-Levine, J., Harms, C., and Fahlman, A. (2019). Using respiratory sinus arrhythmia to estimate inspired tidal volume in the Bottlenose dolphin (Tursiops truncatus). Front. Physiol. 10:128. doi: 10.3389/fphys.2019.00128

Costidis, A., and Rommel, S. A. (2012). Vascularization of air sinuses and fat bodies in the head of the Bottlenose dolphin (Tursiops truncatus): morphological implications on physiology. Front. Physiol. 3:243. doi: 10.3389/fphys.2012. 00243

Cox, T. M., Ragen, T. J., Read, A. J., Vos, E., Baird, R. W., Balcomb, K., et al. (2006). Understanding the impacts of anthropogenic sound on beaked whales. J. Cetacean Res. Management 7, 177-187. 
Cozzi, B., Bagnoli, P., Acocella, F., and Constantino, M. L. (2005). Structure and biomechanical properties of the trachea of the striped Dolphin Stenella coeruleoalba: evidence for evolutionary adaptations to diving. Anatomical Record A 284A, 500-510. doi: 10.1002/ar.a.20182

Davenport, J., Cotter, L., Rogan, E., Kelliher, D., and Murphy, C. (2013). Structure, material characteristics and function of the upper respiratory tract of the pygmy sperm whale. J. Exp. Biol. 216, 4639-4646. doi: 10.1242/jeb.083782

Davenport, J., Jones, T. T., Work, T. M., and Balazs, G. H. (2014). Unique characteristics of the trachea of the juvenile leatherback turtle facilitate feeding, diving and endothermy. J. Exp. Mar. Biol. Ecol. 450, 40-46. doi: 10.1016/j. jembe.2013.10.013

Denison, D. M., and Kooyman, G. L. (1973). The structure and function of the small airways in pinniped and sea otter lungs. Respirat. Physiol. 17, 1-10. doi: 10.1016/0034-5687(73)90105-9

Denison, D. M., Warrell, D. A., and West, J. B. (1971). Airway structure and alveolar emptying in the lungs of sea lions and dogs. Respirat. Physiol. 13, 253-260. doi: 10.1016/0034-5687(71)90029-6

Denk, M. A., Fahlman, A., Dennison-Gibby, S., Song, Z., and Moore, M. (2020). Hyperbaric tracheobronchial compression in cetaceans and pinnipeds. J. Exp. Biol. 223:jeb.217885.

Dennison, S., Fahlman, A., and Moore, M. J. (2012a). The use of diagnostic imaging for identifying abnormal gas accumulations in cetaceans and pinnipeds. Front. Physiol. 3:181. doi: 10.3389/fphys.2012.00181

Dennison, S., Moore, M. J., Fahlman, A., Moore, K., Sharp, S., Harry, C. T., et al. (2012b). Bubbles in live-stranded dolphins. Proc. R. Soc. B 79, 1396-1404. doi: $10.1098 /$ rspb.2011.1754

DeRuiter, S. L., Southall, B. L., Calambokidis, J., Zimmer, W. M. X., Sadykova, D., Falcone, E. A., et al. (2013). First direct measurements of behavioural responses by Cuvier's beaked whales to mid-frequency active sonar. Biol. Lett. 9:20130223. doi: $10.1098 / \mathrm{rsbl} .2013 .0223$

Eckenhoff, R. G., Olstad, C. S., and Carrod, G. (1990). Human dose-response relationship for decompression and endogenous bubble formation. J. Appl. Physiol. 69, 914-918. doi: 10.1152/jappl.1990.69.3.914

Elmegaard, S. L., Johnson, M., Madsen, P. T., and Mcdonald, B. I. (2016). Cognitive control of heart rate in diving harbor porpoises. Curr. Biol. 26, R1167-R1176.

Elsner, R. (1965). Heart rate response in forced versus trained experimental dives in pinnipeds. Hvalrådets Skrifter 48, 24-29.

Elsner, R., Kenney, D. W., and Burgess, K. (1966). Diving bradycardia in the trained dolphin. Nature 212, 407-408. doi: 10.1038/212407a0

Ersson, A., Linder, C., Ohlsson, K., and Ekholm, A. (1998). Cytokine response after acute hyperbaric exposure in the rat. Undersea Hyperb. Med. 25, 217-221.

Fahlman, A. (2017). Allometric scaling of decompression sickness risk in terrestrial mammals; cardiac output explains risk of decompression sickness. Sci. Rep. 7:40918.

Fahlman, A., Borque-Espinosa, A., Facchin, F., Ferrero Fernandez, D., Muñoz Caballero, P., Haulena, M., et al. (2020a). Comparative respiratory physiology in cetaceans. Front. Physiol. 11:142. doi: 10.3389/fphys.2020.00142

Fahlman, A., Cozzi, B., Manley, M., Jabas, S., Malik, M., Blawas, A., et al. (2020b). Conditioned variation in heart rate during static breath-holds in the Bottlenose dolphin (Tursiops truncatus). Front. Physiol. 11:604018. doi: 10.3389/fphys. 2020.604018

Fahlman, A., Meegan, J., Borque Espinosa, A., and Jensen, E. D. (2020c). Pulmonary function and resting metabolic rates in California sea lions (Zalophus californianus) in water and on land. Aquatic Mammals 46, 67-79. doi: 10.1578/am.46.1.2020.67

Fahlman, A., Sato, K., and Miller, P. (2020d). Improving estimates of diving lung volume in air-breathing marine vertebrates. J. Exp. Biol. 223:jeb216846. doi: 10.1242/jeb.216846

Fahlman, A., Brodsky, M., Miedler, S., Dennison, S., Ivančić, M., Levine, G., et al. (2019a). Ventilation and gas exchange before and after voluntary static surface breath-holds in clinically healthy Bottlenose dolphins. Tursiops truncatus. J. Exp. Biol. 222:jeb192211. doi: 10.1242/jeb.192211

Fahlman, A., Miedler, S., Rocho-Levine, J., Jabois, A., Arenarez, J., Marti-Bonmati, L., et al. (2019b). Re-evaluating the significance of the dive response during voluntary surface apneas in the Bottlenose dolphin. Tursiops truncatus. Sci. Rep. 9:8613.

Fahlman, A., Brodsky, M., Wells, R., Mchugh, K., Allen, J., Barleycorn, A., et al. (2018a). Field energetics and lung function in wild Bottlenose dolphins, Tursiops truncatus, in Sarasota Bay Florida. Royal Soc. Open Sci. 5, 171280. doi: 10.1098/ rsos. 171280

Fahlman, A., Jensen, F., Tyack, P. L., and Wells, R. (2018b). Modeling tissue and blood gas kinetics in coastal and offshore common Bottlenose dolphins, Tursiops truncatus. Front. Physiol. 9:838. doi: 10.3389/fphys.2018.00838

Fahlman, A., Mchugh, K., Allen, J., Barleycorn, A., Allen, A., Sweeney, J., et al. (2018c). Resting metabolic rate and lung function in wild offshore common Bottlenose dolphins, Tursiops truncatus, near Bermuda. Front. Physiol. 9:886. doi: 10.3389/fphys.2018.00886

Fahlman, A., Crespo Picazo, J.-L., Sterba-Boatwright, B., Stacy, B. A., and GarciaParraga, D. (2017a). Defining risk variables causing gas embolism in loggerhead sea turtles (Caretta caretta) caught in trawls and gillnets. Sci. Rep. 7:2739.

Fahlman, A., Moore, M. J., and Garcia-Parraga, D. (2017b). Respiratory function and mechanics in pinnipeds and cetaceans. J. Exp. Biol. 220, 1761-1763. doi: $10.1242 /$ jeb. 126870

Fahlman, A., Hooker, S. K., Olszowka, A., Bostrom, B. L., and Jones, D. R. (2009). Estimating the effect of lung collapse and pulmonary shunt on gas exchange during breath-hold diving: the scholander and kooyman legacy. Respiratory Physiol. Neurobiol. 165, 28-39. doi: 10.1016/j.resp.2008.09.013

Fahlman, A., and Kayar, S. R. (2003). Probabilistic modelling for estimating gas kinetics and decompression sickness risk in pigs during $\mathrm{H}-2$ biochemical decompression. Bull. Mathemat. Biol. 65, 747-766. doi: 10.1016/s00928240(03)00038-7

Fahlman, A., Loring, S. H., Ferrigno, M., Moore, C., Early, G., Niemeyer, M., et al. (2011). Static inflation and deflation pressure-volume curves from excised lungs of marine mammals. J. Exp. Biol. 214, 3822-3828. doi: 10.1242/jeb.056366

Fahlman, A., Loring, S. H., Johnson, S., Haulena, M., Trites, A. W., Fravel, V. A., et al. (2014a). Inflation and deflation pressure-volume loops in anesthetized pinnipeds confirms compliant chest and lungs. Front. Physiol. 5:433. doi: 10. 3389/fphys.2014.00433

Fahlman, A., Tyack, P. L., Miller, P. J., and Kvadsheim, P. H. (2014b). How manmade interference might cause gas bubble emboli in deep diving whales. Front. Physiol. 5:13. doi: 10.3389/fphys.2014.00013

Fahlman, A., Loring, S. H., Levine, G., Rocho-Levine, J., Austin, T., and Brodsky, M. (2015). Lung mechanics and pulmonary function testing in cetaceans. J. Exp. Biol. 218, 2030-2038. doi: 10.1242/jeb.119149

Fahlman, A., and Madigan, J. (2016). Respiratory function in voluntary participating Patagonia sea lions in sternal recumbency. Front. Physiol. 7:528. doi: $10.3389 /$ fphys.2016.00528

Fahlman, A., Moore, M. J., Trites, A. W., Rosen, D. A. S., Haulena, M., Waller, N., et al. (2016). Dive, food and exercise effects on blood microparticles in Steller sea lions (Eumetopias jubatus): exploring a biomarker for decompression sickness. Am. J. Physiology-Regulatory Integrat. Comparat. Physiol. 310, R596-R601.

Fahlman, A., Olszowka, A., Bostrom, B., and Jones, D. R. (2006). Deep diving mammals: dive behavior and circulatory adjustments contribute to bends avoidance. Respiratory Physiol. Neurobiol. 153, 66-77. doi: 10.1016/j.resp.2005. 09.014

Fahlman, A., Schmidt, A., Jones, D. R., Bostrom, B. L., and Handrich, Y. (2007). To what extent does N2 limit dive performance in king penguins? J. Exp. Biol. 210, 3344-3355. doi: 10.1242/jeb.008730

Fahlman, A., Svärd, C., Rosen, D. A. S., Jones, D. R., and Trites, A. W. (2008). Metabolic costs of foraging and the management of $\mathrm{O} 2$ and $\mathrm{CO} 2$ stores in Steller sea lions. J. Exp. Biol. 211, 3573-3580. doi: 10.1242/jeb.023655

Fahlman, A., Svärd, C., Rosen, D. A. S., Wilson, R. S., and Trites, A. W. (2013). Activity as a proxy to estimate metabolic rate and to partition the metabolic cost of diving vs. breathing in pre- and post-fasted Steller sea lions. Aquatic Biol. 18, 175-184. doi: 10.3354/ab00500

Fahlman, A., Tikuisis, P., Himm, J. F., Weathersby, P. K., and Kayar, S. R. (2001). On the likelihood of decompression sickness during $\mathrm{H} 2$ biochemical decompression in pigs. J. Appl. Physiol. 91, 2720-2729. doi: 10.1152/jappl.2001. 91.6.2720

Farhi, L. E. (1967). Elimination of inert gas by the lung. Respiration Physiol. 3, 1-11. doi: 10.1016/0034-5687(67)90018-7

Farhi, L. E., and Yokoyama, T. (1967). Effects of ventilation-perfusion inequality on elimination of inert gases. Respirat. Physiol. 3, 12-20. doi: 10.1016/00345687(67)90019-9

Fernandez, A., Edwards, J. F., Rodruiquez, F., Espinosa, De Los Monteros, A., Herraez, M. P., et al. (2005). "Gas and fat embolic syndrome” involving a mass 
stranding of beaked whales (family Ziphiidae) exposed to anthropogenic sonar signals. Vet. Pathol. 42, 446-457. doi: 10.1354/vp.42-4-446

Fernández, A., Sierra, E., Díaz-Delgado, J., Sacchini, S., Sánchez-Paz, Y., SuárezSantana, C., et al. (2017). Deadly acute decompression sickness in Risso's dolphins. Sci. Rep. 7:13621.

Fitz-Clarke, J. R. (2009a). Lung compression effects on gas exchange in human breath-hold diving. Respiratory Physiol. Neurobiol. 165, 221-228. doi: 10.1016/ j.resp.2008.12.006

Fitz-Clarke, J. R. (2009b). Risk of decompression sickness in extreme human breath-hold diving. Undersea Hyperbaric Med. 36, 83-91.

Flynn, E. T. J., and Lambertsen, C. J. (1971). "Calibration of inert gas exchange in the mouse," in Underwater Physiology, ed. C. J. Lambertsen (New York, NY: Academic Press), 179-191. doi: 10.1016/b978-0-12-434750-2.50028-9

Froget, G., Butler, P. J., Woakes, A. J., Fahlman, A., Kuntz, G., Le Maho, Y., et al. (2004). Heart rate and energetics of free-ranging king penguins (Aptenodytes patagonicus). J. Exp. Biol. 207, 3917-3926. doi: 10.1242/jeb.01232

Gabler-Smith, M. K., Westgate, A. J., and Koopman, H. N. (2020). Fatty acid composition and N2 solubility in triacylglycerol-rich adipose tissue: the likely importance of intact molecular structure. J. Exp. Biol. 223:jeb216770. doi: 10.1242/jeb.216770

García-Párraga, D., Crespo-Picazo, J. L., Bernaldo, De Quirós, Y., Cervera, V., Martí-Bonmati, L., et al. (2014). Decompression Sickness ("the bends") in Sea Turtles. Dis. Aquatic Organ. 111, 191-205. doi: 10.3354/dao02790

García-Párraga, D., Lorenzo, T., Ortiz, J.-L., Ortega, J., Crespo-Picazo, J.-L., Cortijo, J., et al. (2018a). Deciphering function of the pulmonary arterial sphincters in loggerhead sea turtles (Caretta caretta). J. Exp. Biol. 221:jeb179820. doi: 10.1242/jeb.179820

García-Párraga, D., Moore, M., and Fahlman, A. (2018b). Pulmonary ventilationperfusion mismatch: a novel hypothesis for how diving vertebrates may avoid the bends. Proc. R. Soc. B 285:20180482. doi: 10.1098/rspb.2018.0482

Harris, M., Berg, W. E., Whitaker, D. M., Twitty, V. C., and Blinks, L. R. (1945). Carbon dioxide as a facilitating agent in the initiation and growth of bubbles in animals decompressed to simulated altitudes. J. General Physiol. 28, 225-240. doi: 10.1085/jgp.28.3.225

Harvey, E. N. (1945). Decompression sickness and bubble formation in blood and tissues. Bull. N. Y. Acad. Med. 21, 505-536.

Hindle, A. G., Young, B. L., Rosen, D. A., Haulena, M., and Trites, A. W. (2010). Dive response differs between shallow- and deep-diving Steller sea lions (Eumetopias jubatus). J. Exp. Biol. Ecol. 394, 141-148. doi: 10.1016/j.jembe. 2010.08.006

Hirsch, J. A., and Bishop, B. (1981). Respiratory sinus arrhythmia in humans: how breathing pattern modulates heart rate. Am. J. Physiol. Heart Circul. Physiol. 241, H620-H629. doi: 10.1016/0378-3782(94)90164-3

Hodanbosi, M., Sterba-Boatwright, B., and Fahlman, A. (2016). Updating a gas dynamics model using estimates for California sea lions (Zalophus californianus). Respiratory Physiol. Neurobiol. 234, 1-8. doi: 10.1016/j.resp. 2016.08.006

Hooker, S. K., and Baird, R. W. (1999). Deep-diving behaviour of the northern bottlenose whale, Hyperoodon ampullatus (Cetacea: Ziphiidae). Proc. R. Soc. London B Biol. Sci. 266, 671-676. doi: 10.1098/rspb.1999.0688

Hooker, S. K., Baird, R. W., and Fahlman, A. (2009). Could beaked whales get the bends? Effect of diving behaviour and physiology on modelled gas exchange for three species: Ziphius cavirostris, Mesoplodon densirostris and Hyperoodon ampullatus. Respiratory Physiol. Neurobiol. 167, 235-246. doi: 10.1016/j.resp. 2009.04.023

Hooker, S. K., Fahlman, A., Moore, M. J., Aguilar, De Soto, N., Bernaldo, et al. (2012). Deadly diving? Physiological and behavioural management of decompression stress in diving mammals. Proc. R. Soc. B 279, 1041-1050.

Hooker, S. K., Miller, P., Johnson, M. P., Cox, O. P., and Boyd, I. L. (2005). Ascent exhalations of Antarctic fur seals: a behavioural adaptation for breath-hold diving? Proc. R. Soc. London Series B 272, 355-363. doi: 10.1098/rspb.2004.2964

Houser, D. S., Dankiewicz-Talmadge, L. A., Stockard, T. K., and Ponganis, P. J. (2010). Investigation of the potential for vascular bubble formation in a repetitively diving dolphin. J. Exp. Biol. 213, 52-62. doi: 10.1242/jeb.028365

Houser, D. S., Howard, R., and Ridgway, S. (2001). Can diving-induced tissue nitrogen supersaturation increase the chance of acoustically driven bubble growth in marine mammals? J. Theoret. Biol. 213, 183-195. doi: 10.1006/jtbi. 2001.2415

Hurley, J. A., and Costa, D. P. (2001). Standard metabolic rate at the surface and during trained submersions in adult California sea lions (Zalophus californianus). J. Exp. Biol. 204, 3273-3281.

Irving, L. (1935). The protection of whales from the danger of caisson disease. Science 81, 560-561. doi: 10.1126/science.81.2110.560

Iverson, S. J. (2009). “Blubber," in Encyclopedia of Marine Mammals (2nd Edn), eds W. F. Perrin, B. Würsig, and J. G. M. Thewissen (London: Academic Press), 115-120. doi: 10.1016/b978-0-12-373553-9.00032-8

Jepson, P. D., Arbelo, M., Deaville, R., Patterson, I. A. P., Castro, P., Baker, J. R., et al. (2003). Gas-bubble lesions in stranded cetaceans. Nature 425, 575-576. doi: $10.1038 / 425575 \mathrm{a}$

Jepson, P. D., Deaville, R., Patterson, I. A. P., Pocknell, A. M., Ross, H. M., Baker, J. R., et al. (2005). Acute and chronic gas bubble lesions in cetaceans stranded in the United Kingdom. Vet. Pathol. 42, 291-305. doi: 10.1354/vp.42-3-291

Jones, D. R., Fisher, H. D., Mctaggart, S., and West, N. H. (1973). Heart rate during breath-holding and diving in the unrestrained harbor seal. Can. J. Zool. 51, 671-680. doi: 10.1139/z73-101

Katsenelson, K., Arieli, R., Arieli, Y., Abramovich, A., Feinsod, M., and Tal, D. (2009). Hyperbaric oxygen pretreatment according to the gas micronuclei denucleation hypothesis reduces neurologic deficit in decompression sickness in rats. J. Appl. Physiol. 107, 558-563. doi: 10.1152/japplphysiol.91557.2008

Kayar, S. R., Aukhert, E. O., Axley, M. J., Homer, L. D., and Harabin, A. L. (1997). Lower decompression sickness risk in rats by intravenous injection of foreign protein. Undersea Hyperb. Med. 24, 329-335.

Koopman, H. N., and Westgate, A. J. (2012). Solubility of nitrogen in marine mammal blubber depends on its lipid composition. J. Exp. Biol. 215, 3856-3863. doi: 10.1242/jeb.074443

Kooyman, G. L. (1973). Respiratory adaptations in marine mammals. Am. Zool. 13, 457-468. doi: 10.1093/icb/13.2.457

Kooyman, G. L., Kerem, D. H., Campbell, W. B., and Wright, J. J. (1973). Pulmonary gas exchange in freely diving Weddell seals (Leptonychotes weddelli). Respirat. Physiol. 17, 283-290. doi: 10.1016/0034-5687(73)90003-0

Kooyman, G. L., Schroeder, J. P., Denison, D. M., Hammond, D. D., Wright, J. J., and Bergman, W. P. (1972). Blood nitrogen tensions of seals during simulated deep dives. Am. J. Physiol. 223, 1016-1020. doi: 10.1152/ajplegacy.1972.223.5. 1016

Kooyman, G. L., and Sinnett, E. E. (1979). Mechanical properties of the harbor porpoise lung, Phocoena phocoena. Respirat. Physiol. 36, 287-300. doi: 10. 1016/0034-5687(79)90042-2

Kooyman, G. L., and Sinnett, E. E. (1982). Pulmonary shunts in Harbor seals and sea lions during simulated dives to depth. Physiol. Zool. 55, 105-111. doi: 10.1086/physzool.55.1.30158447

Kvadsheim, P. H., Miller, P. J. O., Tyack, P. L., Sivle, L. L. D., Lam, F.-P. A., and Fahlman, A. (2012). Estimated tissue and blood $\mathrm{N}_{2}$ levels and risk of in vivo bubble formation in deep-, intermediate- and shallow diving toothed whales during exposure to naval sonar. Front. Physiol. 3:125. doi: 10.3389/fphys.2012. 00125

Laidre, K. L., Heide-Jorgensen, M. P., Dietz, R., Hobbs, R. C., and Jorgensen, O. A. (2003). Deep-diving by narwhals Monodon monoceros: differences in foraging behavior between wintering areas? Mar. Ecol. Prog. Ser. 261, 269-281. doi: $10.3354 /$ meps 261269

Leith, D. E. (1976). Comparative mammalian respiratory mechanics. Physiologist $19,485-510$.

Leith, D. E. (1989). Adaptations to deep breath-hold diving: respiratory and circulatory mechanics. Undersea Hyperbaric Med. 16, 345-353.

Lemaitre, F., Fahlman, A., Gardette, B., and Kohshi, K. (2009). Decompression sickness in breath-hold divers: a review. J. Sports Sci. 27, 1519-1534. doi: $10.1080 / 02640410903121351$

Lillo, R. S. (1988). Effect of $\mathrm{N}_{2}-\mathrm{He}-\mathrm{O}_{2}$ on decompression outcome in rats after variable time-at-depth dives. J. Appl. Physiol. 64, 2042-2052. 10.1152/jappl.1988.64.5.2042

Lillo, R. S., Himm, J. F., Weathersby, P. K., Temple, D. J., Gault, K. A., and Dromsky, D. M. (2002). Using animal data to improve prediction of human decompression risk following air-saturation dives. J. Appl. Physiol. 93, 216-226. doi: 10.1152/japplphysiol.00670.2001 
Lillo, R. S., and Maccallum, M. E. (1991). Decompression comparison of $\mathrm{N}_{2}$ and $\mathrm{O}_{2}$ in rats. Undersea Biomed. Res. 18, 317-331.

Ljubkovic, M., Zanchi, J., Breskovic, T., Marinovic, J., Lojpur, M., and Dujic, Z. (2012). Determinants of arterial gas embolism after scuba diving. J. Appl. Physiol. 112, 91-95. doi: 10.1152/japplphysiol.00943.2011

Mahon, R. T., and Regis, D. P. (2014). Decompression and decompression sickness. Comprehen. Physiol. 4, 1157-1175. doi: 10.1002/cphy.c130039

McDonald, B. I., and Ponganis, P. J. (2012). Lung collapse in the diving sea lion: hold the nitrogen and save the oxygen. Biol. Lett. 8, 1047-1049. doi: 10.1098/ rsbl.2012.0743

McDonald, B. I., and Ponganis, P. J. (2013). Insights from venous oxygen profiles: oxygen utilization and management in diving California sea lions. J. Exp. Biol. 216, 3332-3341. doi: 10.1242/jeb.085985

McElroy, W. D., Whiteley, A. H., Warren, G. H., and Harvey, E. N. (1944). Bubble formation in animals. IV. the relative importance of carbon dioxide concentration and mechanical tension during muscle contraction. J. Cell. Comparat. Physiol. 24, 133-146. doi: 10.1002/jcp.1030240205

Melnikov, V. V. (1997). The arterial system of the sperm whale (Physeter macrocephalus). J. Morphol. 234, 37-50. doi: 10.1002/(sici)1097-4687(199710) 234:1<37::aid-jmor4>3.0.co;2-k

Miller, P., Narazaki, T., Isojunno, S., Suzuki, K., Smout, S. C., and Sato, K. (2016). Body density and diving gas volume of the northern bottlenose whale (Hyperoodon ampullatus). J. Exp. Biol. 219, 2458-2468. doi: 10.1242/jeb.137349

Miller, P. J., Johnson, M. P., Tyack, P. L., and Terray, E. A. (2004). Swimming gaits, passive drag and buoyancy of diving sperm whales Physeter macrocephalus. J. Exp. Biol. 207, 1953-1967. doi: 10.1242/jeb.00993

Miller, P. J. O., Jochens, A., Belabbassi, L., and Bigggs, D. (2007). "Diving behavior of sperm whales in relation to oceanographic characteristics," in Proceedings of the Information Transfer Meeting (ITM) (Washington, DC: BOEM).

Mollerlokken, A., Berge, V. J., Jorgensen, A., Wisloff, U., and Brubakk, A. O. (2006). Effect of a short-acting NO donor on bubble formation from a saturation dive in pigs. J. Appl. Physiol. 101, 1541-1545. doi: 10.1152/japplphysiol.01191.2005

Moore, C., Moore, M. J., Trumble, S., Niemeyer, M., Lentell, B., Mclellan, W., et al. (2014). A comparative analysis of marine mammal tracheas. J. Exp. Biol. 217, 1154-1166. doi: 10.1242/jeb.093146

Moore, M. J., Thom, S. R., and Fahlman, A. (2014). Markers of Decompression Stress of Mass Stranded/Live Caught and Released vs. Single Stranded Marine Mammals. Arlington, TX: Office of Naval Research.

Moore, M. J., Bogomolni, A. L., Dennison, S. E., Early, G., Garner, M. M., Hayward, B. A., et al. (2009). Gas bubbles in seals, dolphins, and porpoises entangled and drowned at depth in gillnets. Vet. Pathol. 46, 536-547. doi: 10.1354/vp.08-vp0065-m-fl

Moore, M. J., and Early, G. A. (2004). Cumulative sperm whale bone damage and the bends. Science 306:2215. doi: 10.1126/science.1105452

Moore, M. J., Thom, S. R., and Fahlman, A. (2015). Markers of Decompression Stress of Mass Stranded/Live Caught and Released vs. Single Stranded Marine Mammals. Arlington, TX: Office of Naval Research.

Narazaki, T., Isojunno, S., Nowacek, D. P., Swift, R., Friedlaender, A. S., Ramp, C., et al. (2018). Body density of humpback whales (Megaptera novaengliae) in feeding aggregations estimated from hydrodynamic gliding performance. PLoS One 13:e0200287. doi: 10.1371/journal.pone.0200287

Olsen, C. R., Hale, F. C., and Elsner, R. (1969). Mechanics of ventilation in the pilot whale. Respirat. Physiol. 7, 137-149. doi: 10.1016/0034-5687(69)90001-2

Papadopoulou, V., Germonpré, P., Cosgrove, D., Eckersley, R. J., Dayton, P. A., Obeid, G., et al. (2018). Variability in circulating gas emboli after a same scuba diving exposure. Eur. J. Appl. Physiol. 118, 1255-1264. doi: 10.1007/s00421018-3854-7

Parga, M. L., Crespo-Picazo, J. L., Monteiro, D., García-Párraga, D., Hernandez, J. A., Swimmer, Y., et al. (2020). On-board study of gas embolism in marine turtles caught in bottom trawl fisheries in the Atlantic Ocean. Sci. Rep. 10:5561.

Parker, E. C., Survanshi, S. S., Massell, P. B., and Weathersby, P. K. (1998). Probabilistic models of the role of oxygen in human decompression sickness. J. Appl. Physiol. 84, 1096-1102. doi: 10.1152/jappl.1998.84.3.1096

Paulev, P. (1965). Decompression sickness following repeated breath-hold dives. J. Appl. Physiol. 20, 1028-1031. doi: 10.1152/jappl.1965.20.5.1028

Pedersen, M. B., Fahlman, A., Borque-Espinosa, A., Madsen, P. T., and Jensen, F. H. (2020). Whistling is metabolically cheap for communicating Bottlenose dolphins (Tursiops truncatus). J. Exp. Biol. 223:jeb.212498.
Philp, R. B. (1974). A review of blood changes associated with compressiondecompression: relationship to decompression sickness. Undersea Biomed. Res. $1,117-150$.

Philp, R. B., Bennett, P. B., Andersen, J. C., Fields, G. N., Mcintyre, B. A., Francey, I., et al. (1979). Effects of aspirin and dipyridamole on platelet function, hematology, and blood chemistry of saturation divers. Undersea Biomed. Res. 6, 127-146

Philp, R. B., Inwood, M. J., and Warren, B. A. (1972). Interactions between gas bubbles and components of the blood: implications in decompression sickness. Aerosp. Med. 43, 946-953.

Piantadosi, C. A., and Thalmann, E. D. (2004). Pathology: whales, sonar and decompression sickness. Nature 428, 1-2. doi: 10.1038/nature02527a

Piscitelli, M. A., Mclellan, W. A., Rommel, S. A., Blum, J. E., Barco, S. G., and Pabst, D. A. (2010). Lung size and thoracic morphology in shallow- and deep-diving cetaceans. J. Morphol. 271, 654-673.

Piscitelli, M. A., Raverty, S. A., Lillie, M. A., and Shadwick, R. E. (2013). A review of cetacean lung morphology and mechanics. J. Morphol. 274, 1425-1440. doi: 10.1002/jmor.20192

Ponganis, P. J. (2011). Diving mammals. Comprehensive Physiol. 1, 517-535.

Ponganis, P. J., Kooyman, G. L., Van Dam, R., and Le Maho, Y. (1999). Physiological responses of king penguins during simulated diving to $136 \mathrm{~m}$ depth. J. Exp. Biol. 202, 2819-2822.

Portugues, C., Crespo-Picazo, J. L., García-Párraga, D., Altimiras, J., Lorenzo, T., Borque-Espinosa, A., et al. (2018). Impact of gas emboli and hyperbaric treatment on respiratory function of loggerhead sea turtles (Caretta caretta). Conserv. Physiol. 6:cox074.

Quick, N. J., Cioffi, W. R., Shearer, J. M., Fahlman, A., and Read, A. J. (2020). Extreme diving in mammals: first estimates of behavioural aerobic dive limits in Cuvier's beaked whales. J. Exp. Biol. 225:jeb222109. doi: 10.1242/jeb. 222109

Rahn, H., and Yokoyama, T. (1965). The Physiology of Breath-hold Diving and the Ama of Japan. Papers (Washington, DC: National Academy of Science).

Reed, J. Z., Chambers, C., Fedak, M. A., and Butler, P. J. (1994). Gas exchange of captive freely diving grey seals (Halichoerus grypus). J. Exp. Biol. 191, 1-18. doi: 10.7589/0090-3558-23.1.1

Ridgway, S. H., Carder, D. A., and Clark, W. (1975). Conditioned bardycardia in the sea lion Zalophus californianus. Nature 256, 37-38. doi: 10.1038/256037a0

Ridgway, S. H., and Howard, R. (1979). Dolphin lung collapse and intramuscular circulation during free diving: evidence from nitrogen washout. Science 206, 1182-1183. doi: 10.1126/science.505001

Ridgway, S. H., Scronce, B. L., and Kanwisher, J. W. (1969). Respiration and deep diving in the bottlenose porpoise. Science 166, 1651-1654. doi: 10.1126/science. 166.3913 .1651

Robertson, A. G. (1992). Decompression sickness risk in women. Undersea Hyperbaric Med. 19, 216-217.

Robinson, A. J., Kropatkin, M., and Aggeler, P. M. (1969). Hagemann factor (Factor 12) deficiency in marine mammals. Science 166:1420. doi: 10.1126/science.166. 3911.1420

Robinson, P. W., Costa, D. P., Crocker, D. E., Gallo-Reynoso, J. P., Champagne, C. D., Fowler, M. A., et al. (2012). Foraging behavior and success of a mesopelagic predator in the northeast pacific ocean: insights from a data-rich species, the Northern Elephant Seal. PLoS One 7:e36728. doi: 10.1371/journal. pone. 0036728

Rojano-Doñate, L., Mcdonald, B. I., Wisniewska, D. M., Johnson, M., Teilmann, J., Wahlberg, M., et al. (2018). High field metabolic rates of wild harbour porpoises. J. Exp. Biol. 221:jeb185827. doi: 10.1242/jeb.185827

Sato, K., Charrassin, J.-B. T., Bost, C.-A., and Naito, Y. (2004). Why do macaroni penguins choose shallow body angles that result in longer descent and ascent durations? J. Exp. Biol. 207, 4057-4065. doi: 10.1242/jeb.01265

Sato, K., Mitani, Y., Cameron, M. F., Siniff, D. B., and Naito, Y. (2003). Factors affecting stroking patterns and body angle in diving Weddell seals under natural conditions. J. Exp. Biol. 206, 1461-1470. doi: 10.1242/jeb.00265

Sato, K., Shiomi, K., Marshall, G., Kooyman, G. L., and Ponganis, P. J. (2011). Stroke rates and diving air volumes of emperor penguins: implications for dive performance. J. Exp. Biol. 214, 2854-2863. doi: 10.1242/jeb.055723

Schipke, J. D., Gams, E., and Kallweit, O. (2006). Decompression sickness following breath-hold diving. Res. Sports Med. 14, 163-178. doi: 10.1080/ 15438620600854710 
Scholander, P. F. (1940). Experimental investigations on the respiratory function in diving mammals and birds. Hvalrådets Skrifter 22, 1-131.

Schorr, G. S., Falcone, E. A., Moretti, D. J., and Andrews, R. D. (2014). First LongTerm behavioral records from cuvier's beaked whales (Ziphius cavirostris) reveal record-breaking dives. PLoS One 9:e92633. doi: 10.1371/journal.pone.0092633

Shearer, J. M., Quick, N. J., Cioffi, W. R., Baird, R. W., Webster, D. L., Foley, H. J., et al. (2019). Diving behaviour of Cuvier's beaked whales (Ziphius cavirostris) off cape hatteras, North Carolina. R. Soc. Open Sci. 6:181728. doi: 10.1098/rsos. 181728

Stevens, D. M., Gartner, S. L., Pearson, R. R., Flynn, E. T., Mink, R. B., Robinson, D. H., et al. (1993). Complement activation during saturation diving. Undersea Hyperb. Med. 20, 279-288.

Sumich, J. L. (2001). Direct and indirect measures of oxygen extraction, tidal lung volumes and respiratory rates in a rehabilitating gray whale calf. Aquatic Mammals 27, 279-283.

Sumich, J. L., and May, M. A. (2009). Scaling and remote monitoring of tidal lung volumes of young gray whales, Eschrichtius robustus. Mar. Mammal Sci. 25, 221-228. doi: 10.1111/j.1748-7692.2008.00272.x

Tarasoff, F. J., and Kooyman, G. L. (1973). Observations on the anatomy of the respiratory system of the river otter, sea otter, and harp seal. II The trachea and bronchial tree. Can. J. Zool. 51, 171-177. doi: 10.1139/z73-025

Temple, D. J., Ball, R., Weathersby, P. K., Parker, E. C., and Survanshi, S. S. (1999). The Dive Profiles and Manifestations of Decompression Sickness Cases After Air and Nitrogen-Oxygen Dives. Volume 1: Data Set Summaries, Manifestation Descriptions, and Key Files. NMRC 99-02 Bethesda, MD: Naval Medical Research Center.

Thom, S. R., Bennett, M., Banham, N. D., Chin, W., Blake, D. F., Rosen, A., et al. (2015). Association of microparticles and neutrophil activiation with decompression sickness. J. Appl. Physiol. 119, 427-434.

Thom, S. R., Milovanova, T. N., Bogush, M., Bhopale, V. M., Yang, M., Bushmann, K., et al. (2012). Microparticle production, neutrophil activation, and intravascular bubbles following open-water SCUBA diving. J. Appl. Physiol. 112, 1268-1278. doi: 10.1152/japplphysiol.01305.2011

Thom, S. R., Milovanova, T. N., Bogush, M., Yang, M., Bhopale, V. M., Pollock, N. W., et al. (2013). Bubbles, microparticles, and neutrophil activation: changes with exercise level and breathing gas during open-water SCUBA diving. J. Appl. Physiol. 114, 1396-1405. doi: 10.1152/japplphysiol.00106.2013

Thom, S. R., Yang, M., Bhopale, V. M., Huang, S., and Milovanova, T. N. (2011). Microparticles initiate decompression-induced neutrophil activation and subsequent vascular injuries. J. Appl. Physiol. 110, 340-351. doi: 10.1152/ japplphysiol.00811.2010

Thompson, L. A., and Romano, T. A. (2015). Beluga (Delphinapterus leucas) granulocytes and monocytes display variable responses to in vitro pressure exposures. Front. Physiol. 6:128. doi: 10.3389/fphys.2015.00128

Thompson, L. A., and Romano, T. A. (2016). Pressure induced changes in adaptive immune function in belugas (Delphinapterus leucas); implications for dive physiology and health. Front. Physiol. 7:442. doi: 10.3389/fphys.2016.00442

Thompson, L. A., and Romano, T. A. (2019). Effects of health status on pressureinduced changes in phocid immune function and implications for dive ability. J. Comp. Physiol. B 189, 637-657. doi: 10.1007/s00360-019-01228-6

Tyack, P. L., Johnson, M., Aguilar, De Soto, N., Sturlese, A., and Madsen, P. T. (2006). Extreme diving of beaked whales. J. Exp. Biol. 209, 4238-4253. doi: 10.1242/jeb.02505

Van Bonn, W., Dennison, S., Cook, P., and Fahlman, A. (2013). Gas bubble disease in the brain of a living California sea lion (Zalophus californianus). Front. Aquatic Physiol. 4:5. doi: 10.3389/fphys.2013.00005

Van Bonn, W., Montie, E., Dennison, S., Pussini, N., Cook, P., Greig, D., et al. (2011). Evidence of injury caused by gas bubbles in a live marine mammal: barotrauma in a California sea lion Zalophus californianus. Dis. Aquatic Organ 96, 89-96. doi: 10.3354/dao02376

van der Hoop, J. M., Fahlman, A., Hurst, T., Rocho-Levine, J., Shorter, A. K., Petrov, V., et al. (2014). Bottlenose dolphins modify behavior to reduce metabolic effect of tag attachment. J. Exp. Biol. 217, 4229-4236. doi: 10.1242/jeb.108225

Vann, R. D., Butler, F. K., Mitchell, S. J., and Moon, R. E. (2011). Decompression illness. Lancet 377, 153-164.
Vogl, A. W., and Fisher, H. D. (1982). Arterial retia related to supply of the central nervous system in two small toothed whales - narwhal (Monodon monoceros) and beluga (Delphinapterus leucas). J. Morphol. 174, 41-56. doi: 10.1002/jmor. 1051740105

Ward, C. A., Koheil, A., Mccullough, D., Johnson, W. R., and Fraser, W. D. (1986), Activation of complement at plasma-air or serum-air interface of rabbits. J. Appl. Physiol. 60, 1651-1658.

Ward, C. A., Mccullough, D., and Fraser, W. D. (1987). Relation between complement activation and susceptibility to decompression sickness. J. Appl. Physiol. 62, 1160-1166. doi: 10.1152/jappl.1987.62.3.1160

Ward, C. A., Mccullough, D., Yee, D., Stanga, D., and Fraser, W. D. (1990). Complement activation involvement in decompression sickness of rabbits. Undersea Biomed. Res. 17, 51-66.

Weathersby, P. K., and Homer, L. (1980). Solubility of inert gases in biological fluids and tissues: a review. Undersea Biomed. Res. 7, 277-296.

Weathersby, P. K., Homer, L. D., and Flynn, E. T. (1984). On the likelihood of decompression sickness. J. Appl. Physiol. 57, 815-825.

Weathersby, P. K., Survanshi, S. S., Homer, L. D., Parker, E., and Thalmann, E. D. (1992). Predicting the time of occurrence of decompression sickness. J. Appl. Physiol. 72, 1541-1548. doi: 10.1152/jappl.1992.72.4.1541

Wells, R. S. (2009). Learning From Nature: Bottlenose Dolphin Care and Husbandry. Zoo Biol. 28, :635-651.

Wells, R. S. (2014). "Social structure and life history of Bottlenose Dolphins near sarasota bay, florida: insights from four decades and five generations," in Primates and Cetaceans: Field Research and Conservation of Complex Mammalian Societies, eds J. Yamagiwa and L. Karczmarski (Tokyo: Primatology Monographs, Springer).

Wells, R. S. (2020). The sarasota dolphin research program in 2020: celebrating 50 years of research, conservation, and education. Aquatic Mammals 25, 502-503. doi: $10.1578 / \mathrm{am} .46 .5 .2020 .502$

Wells, R. S., Rhinehart, H. L., Hansen, L. J., Sweeney, J. C., Townsend, F. I., Stone, R., et al. (2004). Bottlenose dolphins as marine ecosystem sentinels: developing a health monitoring system. EcoHealth 1, 246-254.

Williams, T. M., Friedl, W. A., and Haun, J. E. (1993). The physiology of Bottlenose dolphins (Tursiops truncatus): heart rate, metabolic rate and plasma lactate concentration during exercise. J. Exp. Biol. 179, 31-46.

Williams, T. M., Haun, J. E., and Friedl, W. A. (1999). The diving physiology of Bottlenose dolphins (Tursiops truncatus). I. balancing the demands of exercise for energy conservation at depth. J. Exp. Biol. 202, 2739-2748.

Yamashita, K., Fujinaga, T., Hagio, M., Miyamoto, T., Izumisawa, Y., and Kotani, T. (1994). Bioassay for interleukin-1, interleukin-6, and tumor necrosis factorlike activities in canine sera. J. Vet. Med. Sci. 56, 103-107. doi: 10.1292/jvms. 56.103

Yang, M., Milovanova, T. N., Bogush, M., Uzun, G., Bhopale, V. M., and Thom, S. R. (2011). Microparticle enlargement and altered surface proteins after air decompression are associated with inflammatory vascular injuries. J. Appl. Physiol. 112, 204-211. doi: 10.1152/japplphysiol.00953.2011

Zimmer, W. M. X., and Tyack, P. L. (2007). Repetitive shallow dives pose decompression risk in deep-diving beaked whales. Mar. Mammal Sci. 23, 888-925. doi: 10.1111/j.1748-7692.2007.00152.x

Conflict of Interest: AF was employed by the company Global Diving Research, Inc.

The remaining authors declare that the research was conducted in the absence of any commercial or financial relationships that could be construed as a potential conflict of interest.

Copyright (c) 2021 Fahlman, Moore and Wells. This is an open-access article distributed under the terms of the Creative Commons Attribution License (CC BY). The use, distribution or reproduction in other forums is permitted, provided the original author(s) and the copyright owner(s) are credited and that the original publication in this journal is cited, in accordance with accepted academic practice. No use, distribution or reproduction is permitted which does not comply with these terms. 